\title{
Groundwater Development and Management Practices in Lake Awassa Catchment, Southern Ethiopia
}

\author{
Legesse Begashaw Zemedagegnehu \\ Ethiopian Institute of water Resources, Addis Ababa University, PhD Candidate, P.O.Box: 1176,Addis Ababa, \\ Ethiopia
}

\begin{abstract}
The amount of groundwater that is currently being used for domestic and non-domestic purposes in the basin is 17.8 million cubic meter. The net total amount of water that is actually available to recharge the groundwater circulation within the Lake Awassa catchment is 218.79 million cubic meter. Currently, 233 groundwater structures are found developed in different parts of the study area. Out of these 49 are non functional. Among the developed groundwater structures dominantly nonfunctional is hand dug wells, which comprises $29.55 \%$ of the total constructed hand dug wells. The hand dug wells are followed by shallow wells $(25 \%)$, springs $(19.75 \%)$ and boreholes (10\%). Poor management of the constructed schemes, lack of awareness at community level, spare part problems, and construction problems are the major causes of the failure of the groundwater structures. Utilization of groundwater in the functional ones is not conducted on the basis of recommended values that were set based on the hydrogeological parameters during the development of the structures. Discharging hours are increased to satisfy the water demands of different users. Currently, groundwater is developed without groundwater management plan in uncoordinated manner by governmental and nongovernmental organizations and also privately.At present, the amount of natural recharge in the basin is more than the abstraction. The problem is not lack of water; it is rather absence of or poor management. This is mainly due to lack of efficient groundwater management organization at sub-basin level. Management of groundwater resources is crucial for better development and optimum utilization of the groundwater resources of the basin and to avoid any adverse effects. Therefore it is necessary to establish an efficient groundwater management organization that can conduct detailed groundwater management studies of the basin, follow the objectives of the national water resources management policy and also effectively implement.
\end{abstract}

Keywords: Aquifer ; Ethiopia;Groundwater management; Hydrogeology;Lake Awsasa

DOI: $10.7176 / \mathrm{JEES} / 10-12-01$

Publication date: December $31^{\text {st }} 2020$

\section{Introduction}

Groundwater is one of the earth's most widely distributed natural resources. It has been a source of water supply since the dawn of recorded history. Many great economic developments have been made possible through the use of groundwater. Groundwater represents a major source of water for drinking and industrial uses. It also contributes a considerable share to irrigated agriculture. It is a unique resource, widely available, providing security against droughts and yet closely linked to surface water resources and the hydrological cycle. Its reliable supply, uniform quality and temperature, relative turbidity and pollution free, minimal evaporation losses, and low cost of development are attributes making groundwater more attractive when compared to surface water. Yet, at the same time population and economic growth have led to ever more demands on the groundwater resources and in many countries there are already significant impacts due to inadequately-regulated groundwater pumping and/or from pollution due to inadequate management.

In view of this, management of groundwater has become one of the most significant issues in recent times.

Over $70 \%$ of Ethiopia's drinking water comes from shallow and deep groundwater sources. Yet, groundwater investigation, development, administration, conservation, protection, control and utilization - is not adequately developed [1]. Surface water and groundwater are the sources of water supply for domestic consumption in Lake Awassa catchment. The gap between the water demand and supply is continually increasing being aggravated by the immense and fast development of the towns in the catchment. A number of wells are drilled and springs are also developed to supplement the water supply and by then minimize the gaps between the demand and the supply. Even though groundwater is extracted and utilized for this purposes, shortage of water supply remain as a chronic problem of the catchment.

The water demand in the Lake Awassa catchment is increased from time to time due to the increment of population.Yet water resources are limited if not properly managed. Groundwater management practices in the catchment are not adequately developed. Even though the water supply coverage of the area increases, a significant number of the water supply schemes in the catchment are non functional due to lack of management. This implies that no effective system of groundwater management practices in the study area.

More than eighty eight deep wells and shallow wells and also several tens of hand dug wells have been constructed in Lake Awassa catchment to supply the water for domestic and industrial purposes. A number of 
springs have also been developed to supply water for domestic purposes. In spite of these numbers of deep wells, shallow wells, developed springs, and surface water supply the gap between the catchment's water demand and supply is continually increasing being aggravated by establishment of a number of large and small scale industries. To satisfy this increasing water demand, currently the responsible bodies are highly engaged in the development of new groundwater sources as an additional source of supply.

Ideally, before groundwater is developed in a certain area or a basin, an investigation of the groundwater resource should be made. In Lake Awassa catchment, a number of groundwater resource potential investigations were done by different scholars. Keeping the scale and quality of these investigations in to mind, however, these investigations were not in any scale compiled and used for groundwater development activities in the catchment by responsible organizations. Groundwater development takes place without the knowledge of the groundwater potential of the area. Utilization of this resource, which is developed in this way, is not also supported by designed and planned manner. Pumping and recovery hours for boreholes and springs are not monitored properly. Boreholes are pumped continuously for long period of time to satisfy the water demand of the catchment. All these activities exposed the groundwater resource of the area to mismanagement. Keeping this in view, this research assessed the problems that arise as a result of improper development and utilization of groundwater to recommend management options.

\subsection{General Description of the study area}

The Lake Awassa catchment is found $275 \mathrm{~km}$ south of Addis Ababa and administratively the catchment is divided between South Nations, Nationality and Peoples Regional State in the south and Oromiya Regional State in the north. It is located within the geographical co-ordinates of $6^{\circ} 48^{\prime}-7^{\circ} 14^{\prime} \mathrm{N}$ latitude and $38^{\circ} 16^{\prime}-38^{\circ} 44^{\prime}$ E longitude. The study area is contained within an overlapping pair of Rift floor calderas, Awassa and Corbetti, which contain the small Lake Shalo, and the larger terminal Lake Awassa, respectively[5]. The whole area of the catchment as obtained from 1:50,000 scale topographic map is about $1367 \mathrm{~km}^{2}$ including the surface area of the lake. The recent size of the lake surface area is about $96 \mathrm{~km}^{2}$ and, thus the recent effective catchment area is about $1271 \mathrm{~km}^{2}$. The study area can be accessed through an asphalt road connecting Addis Ababa to Moyale, which is a border town on the way to Kenya. The catchment can be accessed in different direction using quite a lot of all weathered roads.

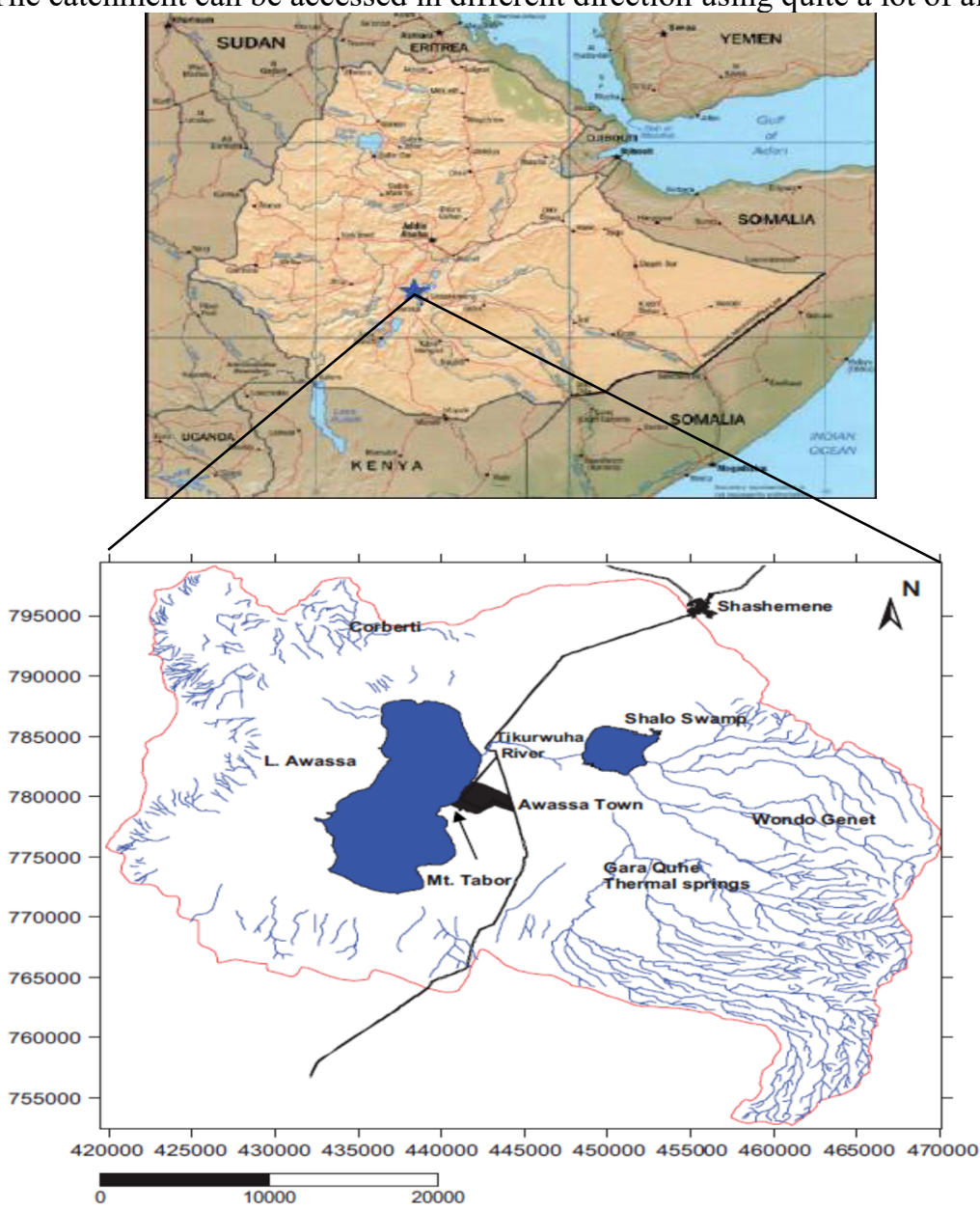

Figure 1. Location map of Lake Awassa catchment. 


\subsubsection{Physiography and Drainage}

The Lake Awassa is situated in the Main Ethiopian Rift Valley system surrounded by flat to gently sloping landforms in the centre of the catchment, and escarpments and hills at the peripheries. The topography of the area is a direct reflection of the volcanic eruption and intensive tectonic activity in the geological time and modification through erosion processes. The central part is made of depression, which is occupied by the perennial lake called Awassa and Shalo swamp (Figure. 2). The lake is located at $1680 \mathrm{~m}$ above sea level (a.s.l.) while the town of Awassa is located at $1685 \mathrm{~m}$ a.s.l. However, the caldera rim rises to $2700 \mathrm{~m}$ a.s.1. The most prominent high points in the center of the basin are Mt. Tabor (1810 m a.s.1.) and Mt. Alamura (2019 m a.s.1.). The landscape of the town and its vicinity gently declines towards lake and the elevation difference between lake and town center is about 5 $\mathrm{m}$ which drives all waters towards the lake[6]. The nested Awassa - Corbetti Caldera complex forms a giant elliptical depression 30-40 km wide on the rift floor [7]. The eastern rolling and dissected plateau comprise high grounds to the eastern margin, aligned approximately NNE - SSW, from Wondo Genet to Wijigra. These are areas of composite landforms that comprise plateaux, medium gradient hills and ridges and include potential recharge source areas for downstream areas. The Wondogent escarpment that lies along the eastern side of the caldera overlaps the eastern rift margin. The easten and southeastern portion,which is characterized by dense drainage system, has streams flowing separately and in a radial pattern, which is the common feature of volcanic area.

The lower plains and swamp areas comprise the flat to gently undulating topography surrounding Lake Awasa. The northwest of the basin, comprising the remnants of the Corbetti caldera, features steep slopes and high relief.

To the west of the lower plains the land rises to composite land forms of moderate to high relief with associated plateaux. This western lake margin suffers significant erosion, accompanied by the formation of gullies.

The highly eroded and most deforested western part of the catchment has relatively flat topography and is massive in nature. It is made of coarse and unwelded pumiceous pyroclastic rocks that have no significant drainage system. It is different from the eastern side, which is covered with fractured ignimbrites and welded tuffs [8].

There are also small scale divides (sub-catchment boundaries) which are the continuation of southern border hills and isolated and scattered cones in between the lake and the shalo swamp. While the wide central part is characterized by very gentle slope and is the one on which the town is built. The bordering scarps and volcanic complexes have an elevation difference varying from 200 to $900 \mathrm{~m}$ [9]. Runoff from the eastern wall of the caldera feeds Shalo swamp. Overflow from Shalo swamp drains into Lake Awassa through the Tikurwoha river. The catchment on the north and northeastern sides consists of perennial streams, draining into Shalo swamp. On the western, northwestern and southern sides of the catchment, no perennial river flow reaches the lake. Many of the ephemeral streams terminate in wide-open faults before they reach the lake. Lake Awassa has no effluent rivers; from a surface water point of view, the Awassa catchment is closed.

\subsubsection{Soils}

Soil classification is based on the physical and chemical characteristics which include depth, color, structural development, texture and evidence of profile development such as presence of diagnostic horizons, reaction to $10 \%$ $\mathrm{HCl}, \mathrm{pH}$ value and others [10]. Alisols, Regosols, Cambisols, Leptosols, Andosols, Vertic Cambisols, Gleysols, Vertic luvisols are some of the soil types described by Water Works Design and Supervision with respect to their position in a different relief intensity and slope. Generally based on their dominant characteristics these soils of the study area are classified in to four groups as clay loam, fine sand, fine sandy loam and silty loam [11]. 


\section{Soil map of lake awassa catchment}

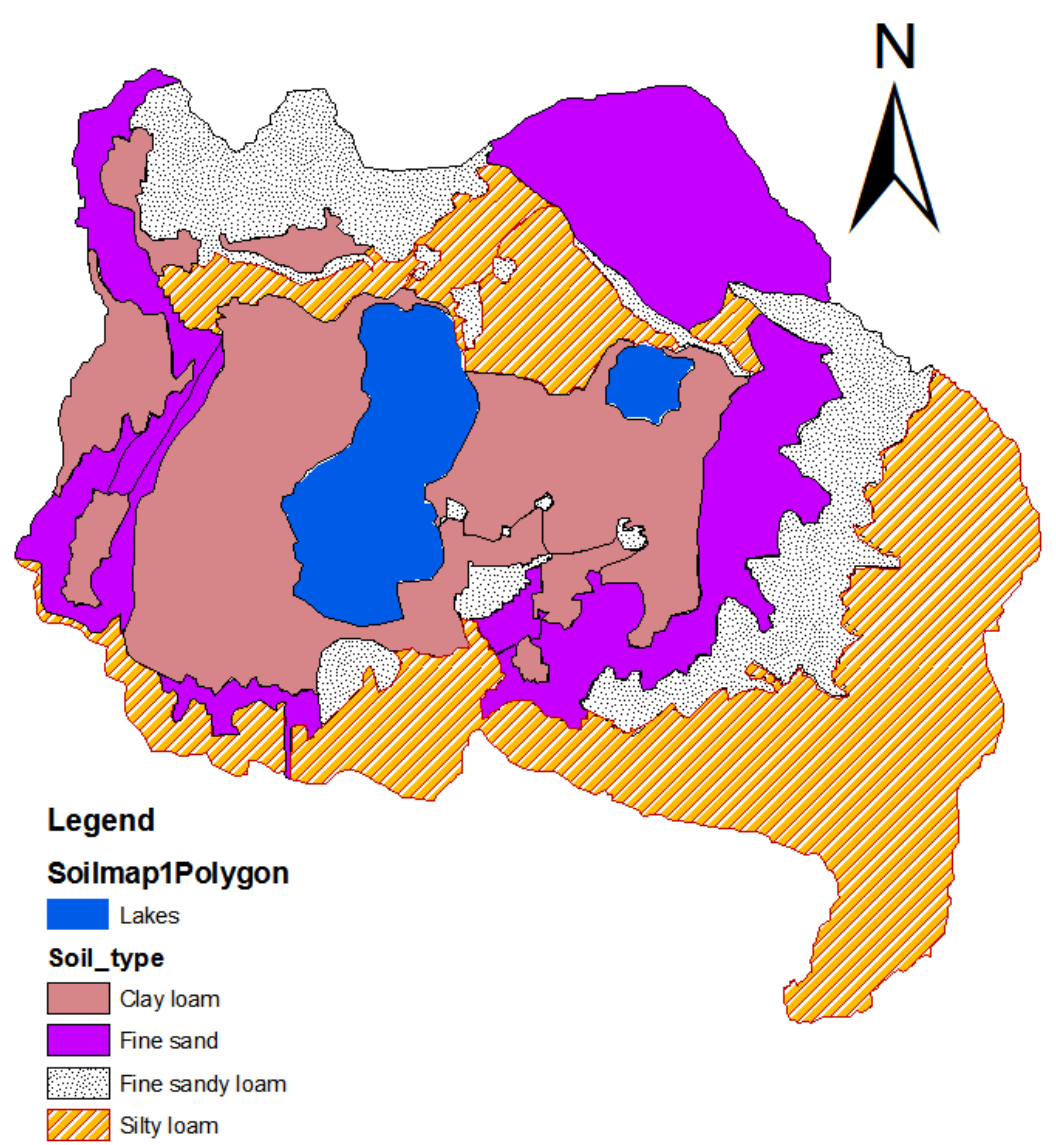

$\begin{array}{llll}0 & 4 & 8 & 16\end{array}$

Kilometers

Figure 3. Soil map of Lake Awassa catchment.

Table 1. Area coverage of the different soil types in Lake Awassa catchment.

\begin{tabular}{lll}
\hline Soil types & Area coverage $\left(\mathrm{km}^{2}\right)$ & Area proportion(\%) \\
Clay loam & 338.63 & 28.44 \\
Fine sand & 269.93 & 22.67 \\
Fine sandy loam & 140.05 & 11.76 \\
Silty loam & 441.99 & 37.13 \\
\hline
\end{tabular}

\subsubsection{Land Use/Land Cover}

The land use of Lake Awassa catchment has been changed progressively due to extreme deforestation as a result of increase in population which results in replacement of vegetation cover by cultivated land. Agriculture is the main land use practice in the catchment and occupies most of the floor of the catchment. Open bushy woodland with moderately cultivated land found on the southern part of the area. Cultivated land with exposed bare rock and soil found on southwest corner of the area. Open grassland with bare soil covering the eastern part of Lake Awassa. Open grassland with open bushy woodland is found covering the volcanic hills of eastern part of the lake.

According to Geological Survey of Ethiopia [8], the dense bushy woodland have been changed to open bush land, open grassland, cultivated land by about $70 \%$ as compared to the situation of the lake watershed 35 years back. The ever-growing demand of wood for fire, charcoal, construction materials, and household furniture has highly influenced the change in land use/land cover condition of the lake catchment. The growth of population in the lake catchment and nearby areas has resulted in encroachment of additional farmland and the depletion of vegetation cover. Currently, much of the catchment is cultivated in unmanaged way that makes the soil even more susceptible to erosion. Hence, this causes the loss of soil and subsequent transport of sediment by streams and river system from upland areas into Shalo swamp and to other low-lying areas in the catchment. 


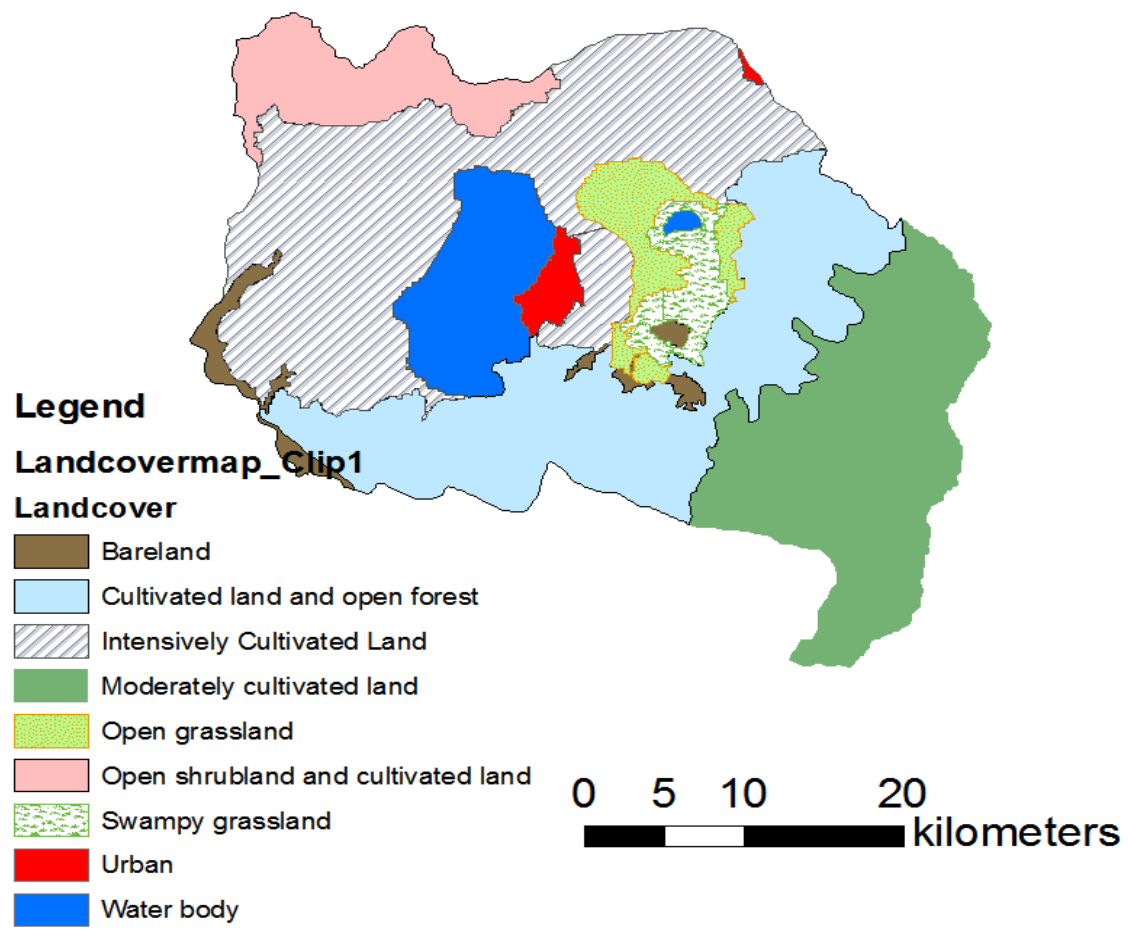

Figure 4. Land use map of Lake Awassa catchment.

Table 2. Land use type with their area proportion and slope range.

\begin{tabular}{lllll}
\hline ID & Major land use types & Total area $\left(\mathrm{km}^{2}\right)$ & Area proportion(\%) & Slope range \\
\hline 1 & Bareland & 31.86 & 2.16 & $2-8$ \\
2 & Intensively cultivated land & 462.62 & 31.37 & $0-2$ \\
3 & Moderately cultivated land with plantation & 295.18 & 20.01 & $2-16$ \\
4 & Cultivated land and open forest & 329.63 & 22.35 & $2-32$ \\
5 & Open grass land & 97.9 & 6.64 & $0-2$ \\
6 & Open shrub land and cultivated land & 95.37 & 6.47 & $0-16$ \\
7 & Swampy grassland & 38.97 & 2.64 & $0-2$ \\
8 & Urban & 18.21 & 1.23 & $0-2$ \\
9 & Waterbody & 105.13 & 7.13 & \\
\hline
\end{tabular}

\subsection{Geology}

The Lake Awassa catchment lies in the Main Ethiopian Rift. The Main Ethiopian Rift is divided based on structural features into three geographic areas; represented by the northern (Fentale-Nazeret), Central (Nazeret-Awassa) and southern (Awassa-Konso) sectors [8]. The central sector, where the Lake Awassa catchment belongs to is a symmetric rift basin where both sides of the rift margins are fully defined except in the region between guraghe and sodo of the western escarpment and in the Shashemane area of the eastern margin [12].

[11] subdivided the geological units into five groups, as follows.

(1) Basalts of the Plateau Trap Series (Late Miocene)

These are the oldest rocks found on the eastern and southeastern part of the caldera wall.

(2) Alkaline and peralkaline silicic rocks (Late Pliocene-Middle Pleistocene)

These cover most of the eastern wall of the caldera, south and southeast plains around Lake Awassa, northeastern, southern, southwestern and northwestern part of the catchment, and the ridges of Wendo Genet.

(3) Basaltic lava flows, hyaloclastites and scoria cones (Recent to Pleistocene) 
This unit is found east, west and northeast of Lake Awassa, and contains basaltic lava flows associated with scoria and hyaloclastites, forming small scattered cones on the caldera floor.

(4) Recent acidic volcanics

This unit covers the plains north and northwest of Lake Awassa around Corbetti volcano and volcanic products in eastern and western caldera floors. It is the youngest volcanic rock, being the Chebbi Volcano products.

(5) Volcano-lacustrine deposits (Pleistocene to Recent)

These deposits cover most of the floor of the rift (caldera), being dominantly derived from volcanic materials with thin diatomite units. They form the most important aquifers in the catchment.

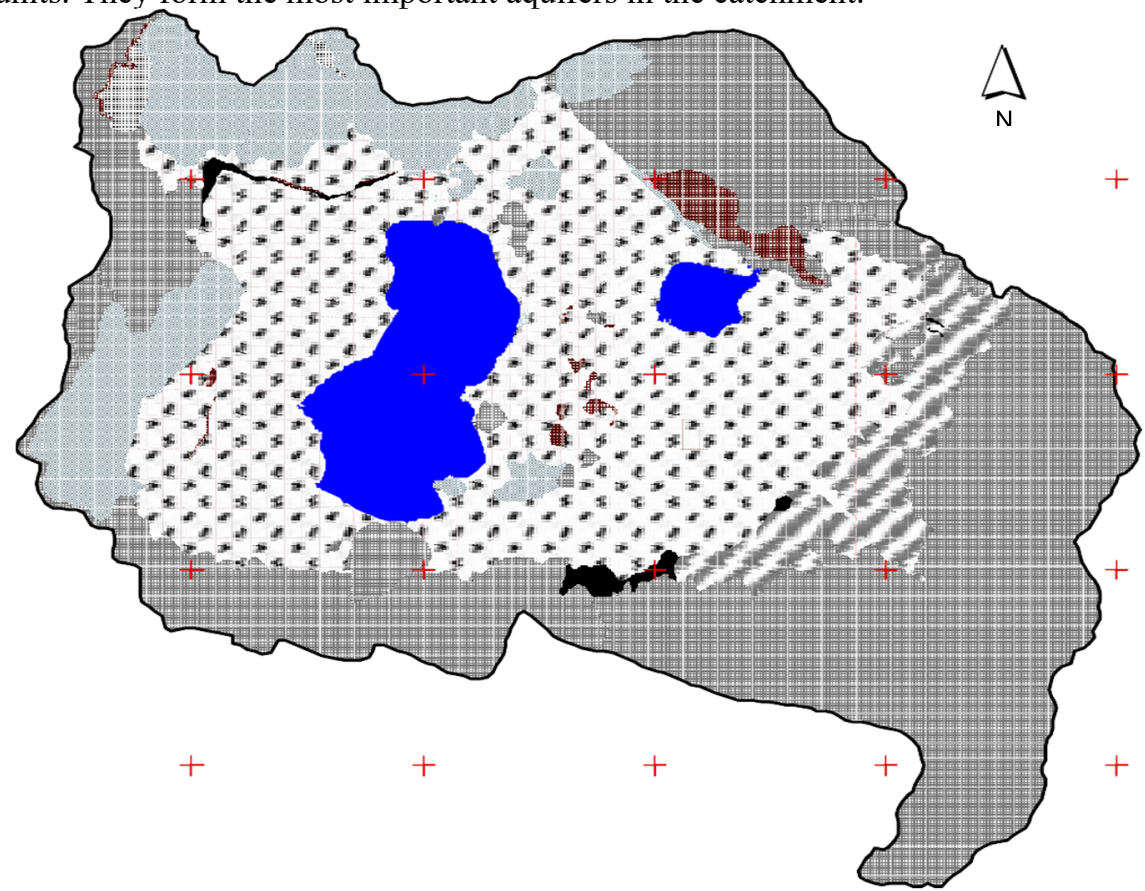

\subsubsection{Hydrogeology}

Figure 5. Geological map of the study area.

Groundwater is stored and transmitted in aquifers. Two properties of aquifers that affect the storage and flow of groundwater are porosity and hydraulic conductivity. Porosity is either primary or secondary and it defines the storage capacity of an aquifer. Groundwater circulation and storage in the volcanic rocks depend on the type of porosity and permeability formed during and after the rock formation [13]. In volcanic or crystalline rocks permeability depends on the size of the opening and how well the cracks or fractures are interconnected. The number and arrangement of fracture openings and the degree to which they are filled by finer grained material control secondary porosity.

The occurrence of groundwater in the studied area is controlled both by primary porosity in lacustrine deposits and secondary porosity in volcanic rocks. Fractured and jointed ignimbrites and the overlying volcano-lacustrine sediments are the two major aquifers in the area. The underlying, down faulted Tertiary ignimbrites, if not buried too deeply, will probably incorporate the most extensive aquifer in the MER [14]. Volanco-lacustrine sediments are composed of aquifers of sand, tuff, and pumice interlayered with clay aquitards. The lacustirne sediment serves as a cap formation, where it is not broken by young Wonji faults, to impede the free movement of geothermal fluid to the surface. The lacustrine sediment has a thickness ranging from 40 to $60 \mathrm{~m}$ [8]. Frequently one or more aquifers, separated by clay aquitards, are encountered in boreholes drilled in the lacustine sediments.

The groundwater in the lacustrine units is generally semi-confined, although may be unconfined, particularly to the west of the lake. Confined conditions occur in the swampy area east of Awasa, where the aquifer is recharged by deep percolating groundwater, probably from the eastern margins. This generates a high hydraulic gradient and the deeper groundwater in the shallow marshy area can be artesian, potentially flowing confined conditions.

Hydrogeological study conducted by [8], pointed out that Lake Awassa catchment is classified qualitatively based on recharge, permeability, aquifer thickness, yield of springs and topography as very high, high, moderate, low and very low potential zones.

The very high potential aquifer encloses the area west of Wondo Genet escarpment, where young alluvial sediment deposits overlay thick lacustrine sediment deposit. It is recharged mainly by overland flow from part of the eastern Ethiopian plateau, and partly from direct precipitation, perennial streams and springs from the eastern highland and recharge from irrigation.

Aquifers found in Awassa - Corbetti caldera zone have high to moderate potential constituting highly 
permeable sediment and unwelded coarse tuff. It has relatively higher aquifer thickness, deep water table and good water quality. This aquifer zone has limited recharge source that is recharge from Shamena escarpment and direct rainfall, during rainy season.

The majority of moderate potential aquifers constitute deeply buried fractured Tertiary ignimbrite aquifer with plentiful good quality perennial springs supplying drinking water for surrounding villages and towns. Tuffs, basalts, scoria, and recent alluvium are other units of this group.

Low to moderate potential aquifers are found in the eastern highland containing mostly welded tuff. Very small amount of water infiltrates out of enormous rainfall where most of it goes as surface runoff to Lake Awassa.

Low potential aquifers are those with thin layer of top clay soil and volcanic ash, it has very low permeability, very low recharge amount, very deep water table and poor water quality.

Pumice, tuff and other pyroclastics which have high permeability constitute very low potential aquifers due to the absence of confining layer which result in deep water table, this area gets lesser direct precipitation than other areas.

The eastern part of the catchment gets better recharge than the western as a result of its higher rainfall amount and perennial streams from the eastern escarpment, in addition to these faults facilitate recharge to the aquifer.

The floor of the catchment gets recharge from precipitation as direct recharge and as indirect from perennial rivers, mainly from Tikurwoha river which is the only perennial river flowing to Lake Awassa.

Southeastern part of the catchment gets the highest recharge due to its high amount of rainfall, characteristic flat topped hill which facilitates infiltration instead of runoff, and its fracture and joints directing stream channels feeding the aquifer.

Discharge areas of the catchment are manifested as swamps, depressions, and cold and hot springs, which are controlled by faults, are found largely in the eastern part of the study area. The swampy area around Lake Shallo is a typical discharge area in the catchment.

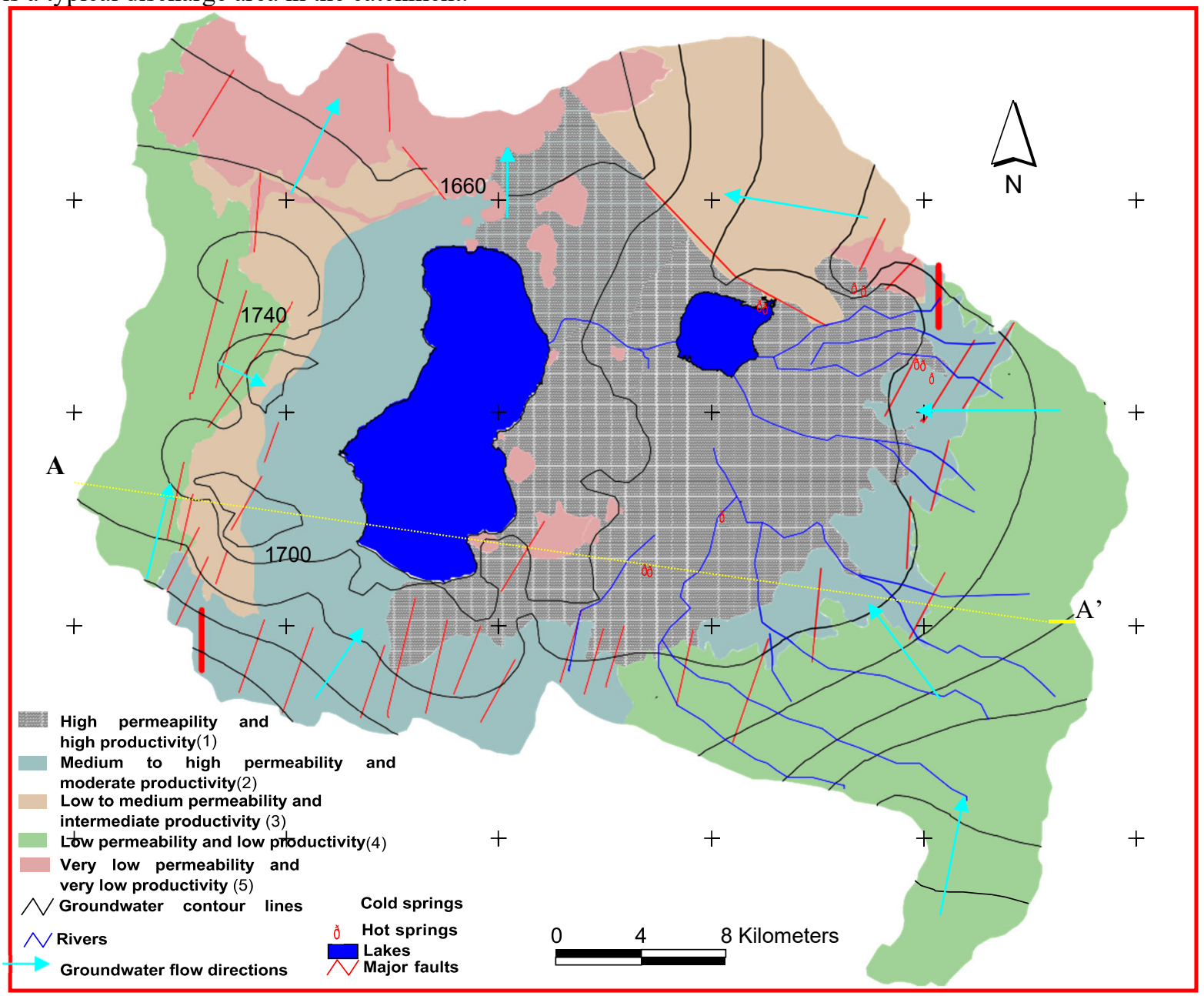

Figure 6. Hydrogeological map of Lake Awasa catchment (modified after Mekonnen, 2005). 


\section{Methods and Materials Used \\ 2.1 Data Collection}

To achieve the objectives of this research work different data such as literatures, meteorological data, stream flow, maps, boreholes, shallow wells, hand-dug wells and spring inventory data have been collected from different sources. Extensive work was carried out by collecting pertinent primary data of the area in the field and secondary data from different offices. The topographic map with a scale of 1:50,000 was used as a base map. Soil map and land use map of the area were prepared using this as a base map.

The hydrology of the basin was characterized by land use, soil, rainfall, temperature, evapotranspiration, wind speed, sunshine hours, relative humidty and runoff. In order to determine the basic hydrologic parameters, meteorological data was collected from the stations in and around the lake Awassa catchment. Data for land use, soil, geology, root depth and slope were collected in the field with the help of GPS and also from previous works. Using ArcGIS 10.4 various thematic maps such as land use, soil, and isohytal map were produced.

There are about six meteorological stations unevenly distributed in and around the catchment. The five stations record only rainfall data, while the one found within Awassa town being first class type, measures almost all the meteorological parameters. For the computation of mean basin rainfall the data from six metereological stations were used. While for the other meteorological parameters only the data obtained from Awassa meteorological station are analyzed thoroughly in the next sections and were used for the computations in this research work.

Three representative district areas with two respective Peasant Association's were selected as survey regions which can characterize the whole water supply problem of the catchment, Wondogenet, Awassa zuria and Awassa town.

The groundwater development activities were assessed with the help of semi-structured questionnaires. For these purposes 8 technical staff members and 5 water resource development office leaders were involved from each district areas.

Current groundwater management practices in the Lake Awassa catchment, information on use of groundwater, awareness about groundwater depletion, the water use permit and management of groundwater structures were determined with the help of semi-structured questionnaires. Samples for these questionnaires were selected from different beneficiaries, water committee leaders and private well owners. For these purposes 5 beneficiaries, 3 water committee leaders from each Peasant Associations and 10 private well owners were participated. The water laws, regulations and their applications were assessed through the interview with government officials. For this purposes 3 government officials were interviewed.

\subsection{Data Processing}

The collected point rainfall data were changed to areal depth of rainfall using isohytal contour map methods. In isohytal contour map methods the average depth of precipitaion is given by:

Where

$$
\bar{R}=\sum_{i=1}^{n} \frac{a_{i} r_{i}}{A}
$$

$\mathrm{R}$ is areal rainfall;

ai is area between adjacent isohytes;

ri is the corresponding mean rainfall; and,

A is the total catchment area.

The mean monthly and annual meteorological parameters were analyzed using microsoft office excel and the estimated values were used to analyze potential (PET) and actual (AET) evapotranspiration.

Textural classification of soil in the study area was used to estimate the maximum water holding capacity. Major land uses in the area were defined and the average depth of the root zone was measured in the field. Taking an active root zone of certain depth, the maximum soil water holding capacity up to the active root zone was estimated. This value of soil water holding capacity was used in the determination of the actual evapotranspiration.

In this study, the Thornthwaite method [2] was used to estimate the potential evapotranspiration of the basin. This method uses air temperature as an index of the energy available for evapotranspiration, assuming that air temperature is correlated with the integrated effects of net radiation and other controls of evapotranspiration, and that the available energy is shared in fixed proportion between heating the atmosphere and evapotranspiration. There is no correction for different vegetation types. The Thornthwaite's empirical equation is:

$$
\text { PETm }=16 \mathrm{Nm}\left[\frac{10 \mathrm{Tm}}{J}\right]_{\mathrm{mm}}^{a}
$$

where 
PETm $=$ Monthly Potential evapotranspiration

$\mathrm{Tm}=$ Mean monthly air temperature $\left({ }^{\circ} \mathrm{C}\right)$

$\mathrm{Nm}=$ a monthly adjustment factor related to hours of daylight

$\mathrm{n}=1,2,3, \ldots \ldots .12$ is the number of the considered months

$\mathrm{J}=$ Annual heat index and it is given by the equation; and

$\mathrm{j}=$ is the monthly heat index and it is expressed as: $\quad J=\sum_{i=1}^{12} j$

$$
\mathrm{j}=(\operatorname{Tn} / 5)^{1.5}
$$

$\mathrm{a}=0.49+0.0179 \mathrm{~J}-0.0000771 \mathrm{~J}^{2}+0.000000675 \mathrm{~J}^{3}$

The computed monthly potential evapotranspiration in Eq. 2 is for a standard month with 360 hours of daylight. It must be corrected for the varying length of day with latitude using the appropriate correction factor.

For the evaluation of the actual evapotranspiration the Thornthwaite water balance model [3] was utilized. The required parameters to determine actual evapotranspiration using this model are mean monthly precipitation, mean monthly potential evapotranspiration, water holding capacity of the dominant soil type and monthly soil moisture storage. The actual evapotranspiration, AET, for the dominant soil types and the respective land use in the area was weighted according to the proportion of the area it represents, and the weighted AET was calculated as:

where $A E T w=\sum_{i=1}^{4}($ AETi $) a i / A$

AETw is weighted actual evapurailspiratıuı

AETi is actual evapotranspiration of the dominant soil types

ai is area of each soil coverage;and,

A is total area of soil coverage.

The volume of runoff from the ungauged catchment were computed by using the runoff coefficient method [4], which employed the following formula:

$\mathrm{Q}=\mathrm{K} . \mathrm{A} . \mathrm{P}$

Where $\mathrm{Q}$ is the runoff from the un-gauged catchment $\left(\mathrm{m}^{3}\right)$

$A$ is the area of the un-gauged catchment $\left(\mathrm{m}^{2}\right)$

$\mathrm{P}$ is the mean annual precipitation $(\mathrm{mm})$; and,

$\mathrm{K}$ is the runoff coefficient.

The water balance for the study area was determined by using the following equation.

Input $=$ out put $\pm \Delta \mathrm{S}$ where, $\Delta \mathrm{S}$ is change in storage.

\section{Results and Discussion \\ 3.1 Hydrology}

\subsubsection{General}

There are well-defined drainage patterns where dense stream networks originate in the mountains situated to east, southeast, and northeast of the lake area and draining the surface runoff in the form of river systems to Lake Shalo. Seasonal courses are also observed in some parts of the watershed by which runoff during rainy season is conveyed directly to Lake Awassa and Lake Shalo. The surface area of Lake Shalo was about $12 \mathrm{~km}^{2}$ in 1972 but currently transformed to swamp with practically no lake surface area [10]. The runoff, which is temporarily, regulated by swamp effect eventually drains via Tikurwoha into Lake Awassa.

The growth of tall grasses in "Lake Shalo" indicates that the lacusterine formation of the lake bed is gradually covered by recent deposition of sediments generated from the watershed and favored the growth of aquatic plants.

As the inflow of sediments is a continuous process and sediment-retarding measures are not implemented, Lake Shalo has been transformed to swamp. The natural regulating reservoir of Lake Shalo has served as transitional impounding reservoir during rainy season and as the high flow recedes gradually the regulated water in the lake drains via Tikurwoha in such a way that stabilization in Lake Awassa maintained before the beginning of the transformation of Lake Shalo in to swampy area.

At present, the surface area of Lake Awassa occupies about 7\% of the total lake catchment area. The town of Awassa lies in an area of about $1 \%$ of the total lake catchment area.

\subsubsection{Rainfall}

According to rainfall distribution analysis and its temporal variability which was done based on rainfall data obtained in and nearer the catchment metrological stations (1991-2010) of NMA (National Meteorological Agency) the study area is characterized by unimodal rainfall pattern zone. The rainfall regime of the study area is characterized by one rainy season, that is, the rainy months are contiguously distributed and the rainfall pattern is unimodal type with only one dry season. The rainfall data taken over the past 20 years $(1991-2010)$ at a station in Awassa town show a slightly modified unimodal rainfall distribution. The first significant rainfall starts in 
March and continues to increase up to May, and then it slightly decreases in June, which finally is, followed by the big rain through July to September.

There are six meteorological stations unevenly distributed in and around the catchment. The station found within Awassa town is the first class type and measures almost all the meteorological parameters. While the other metereological stations record only rainfall data.

Table 3. Mean monthly rainfall at Awassa station (1991-2010).

\begin{tabular}{|c|c|c|c|c|c|c|c|c|c|c|c|c|c|}
\hline Months & Jan & $\mathrm{Feb}$ & Mar & $A p r$ & May & Jun & Jul & Aug & Sep & Oct & Nov & $D e c$ & Annual \\
\hline $\begin{array}{l}\text { Mean } \\
\text { monthly } \\
\text { rainfall } \\
(\mathrm{mm})\end{array}$ & 33.9 & 38.6 & 78.5 & 103.7 & 112.7 & 105.0 & 119.9 & 120.6 & 115.2 & 76.7 & 35.8 & 26.9 & 967.5 \\
\hline
\end{tabular}

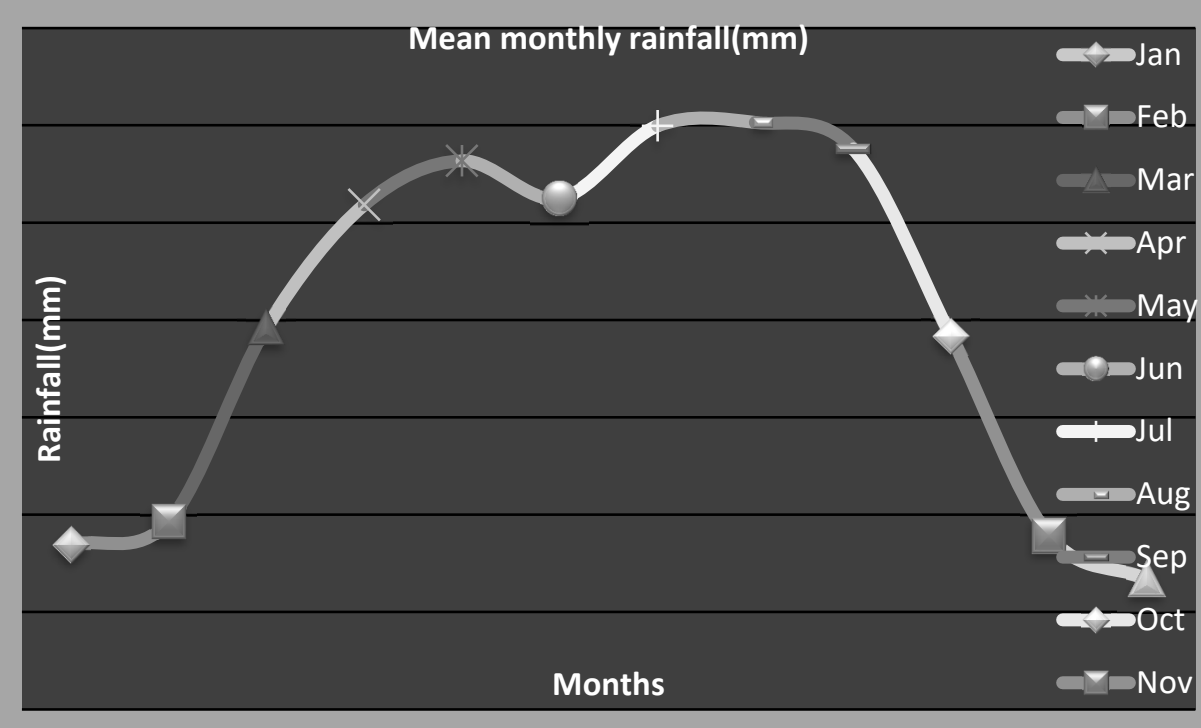

Figure 7. Long-term mean monthly rainfall at Awassa station from 1991 to 2010 (unimodal rainfall pattern).

Table 4. Mean monthly rainfall (mm) at different stations in and around Awassa catchment (1991-2010).

\begin{tabular}{|c|c|c|c|c|c|c|c|c|c|c|c|c|c|}
\hline Stations & Jan & $\mathrm{Feb}$ & Mar & Apr & May & Jun & Jul & Aug & Sep & $O c t$ & Nov & $\mathrm{Dec}$ & Annual \\
\hline Awassa & 33.9 & 38.6 & 78.5 & 103.7 & 112.7 & 105.0 & 119.9 & 120.6 & 115.2 & 76.7 & 35.8 & 26.9 & 967.5 \\
\hline Shashemane & 25.52 & 24.04 & 59.78 & 103.37 & 94.9 & 62.9 & 96.1 & 81.9 & 110.46 & 69.28 & 23.63 & 15.25 & 767.13 \\
\hline Wondogenet & 36.13 & 42.1 & 102.27 & 145.85 & 114.93 & 109.4 & 129.02 & 143.52 & 142.37 & 105.87 & 38.28 & 22.26 & 1132 \\
\hline Morocho & 47.8 & 52.99 & 114.44 & 158.28 & 142.84 & 96.80 & 112.14 & 112.46 & 166.56 & 139.80 & 46.46 & 23.24 & 1213.79 \\
\hline $\begin{array}{l}\text { Telamo } \\
\text { Kentise }\end{array}$ & 35.47 & 43.46 & 118.13 & 188.93 & 181.63 & 116.67 & 132.69 & 125.88 & 178.91 & 139.78 & 39.34 & 26.97 & 1327.84 \\
\hline Haisawita & 31.86 & 43.80 & 117.20 & 153.43 & 134.04 & 84.32 & 104.03 & 120.59 & 157.41 & 101.09 & 33.39 & 29.11 & 1110.25 \\
\hline
\end{tabular}




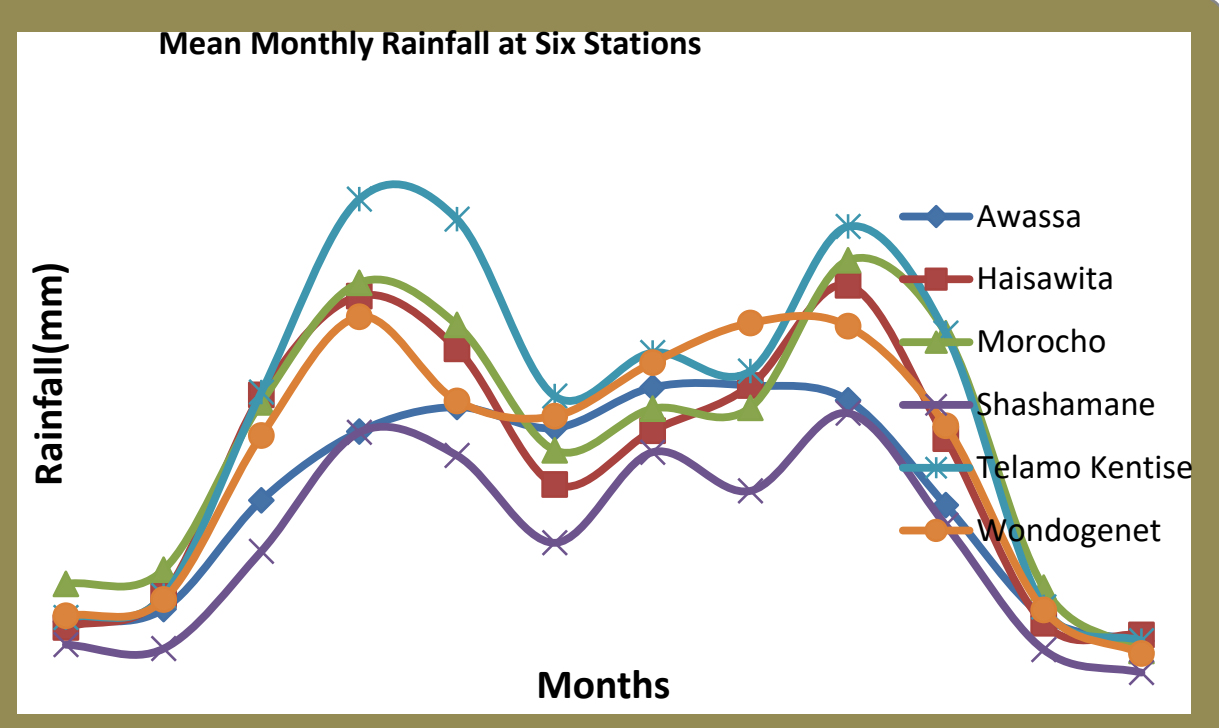

Figure 8. Mean monthly rainfall at different stations in and around Awassa catchment (1991-2010).

\subsubsection{Determination of Aerial Depth of Rainfall}

The rainfall measurement is a point observation and may not be used as a representative value for the area under investigation. Therefore, the point measurements have to be averaged over the study area. To compute aerial depth of precipitation over the catchment isohytal contour map method is used. It consists of drawing lines of equal rainfall depth (isohytes) by interpolation between observed rainfall depths at observed points. The mean value was determined using the formula of Eq. 1. Accordingly, a value of $1039.85 \mathrm{~mm}$ was determined as a mean annual rainfall of the catchment.

Depending on distribution of gauging stations and the effect of topography, validity of arithmetic mean and Thiessen Polygon methods is less. Thiessen polygon method for determing areal rainfall is sound and objective, but it is dependent on a good network of representative gauges [15]. In the study area the network of gauges is poor due to this Thiessen Polygon method is not used. Arthimetic mean is also unreliable because the study area has topography variation that ranges from 1680 to 2700 m.a.s.l. and the stations are not evenly distributed. Therefore, isohytal method is taken to represent the rainfall of the catchment.

Table 5. Annual weighted rainfall depth using Isohytal method.

\begin{tabular}{lllllll}
\hline$I d$ & $P_{i}(\mathrm{~mm})$ & $A_{i}\left(\mathrm{~m}^{2}\right)$ & $A_{t}\left(\mathrm{~m}^{2}\right)$ & $\left(A_{i} / A_{t}\right)$ & $\left(A_{i} / A_{t}\right) * P_{i}$ & $R(\mathrm{~mm})$ \\
\hline 1 & 767.13 & 17098279.694 & 1368089526.93099 & 0.0125 & 9.589 & 1039.85 \\
2 & 875 & 62389333.5503 & 1368089526.93099 & 0.0456 & 39.9 & 1039.85 \\
3 & 925 & 148188490.414 & 1368089526.93099 & 0.1083 & 100.1775 & 1039.85 \\
4 & 975 & 227855948.762 & 1368089526.93099 & 0.167 & 162.825 & 1039.85 \\
5 & 1025 & 187458001.96015 & 1368089526.93099 & 0.137 & 140.425 & 1039.85 \\
6 & 1075 & 301611374.663 & 1368089526.93099 & 0.221 & 237.575 & 1039.85 \\
7 & 1125 & 382120909.037 & 1368089526.93099 & 0.279 & 313.875 & 1039.85 \\
8 & 1175 & 41367188.85054 & 1368089526.93099 & 0.0302 & 35.485 & 1039.85 \\
\hline
\end{tabular}




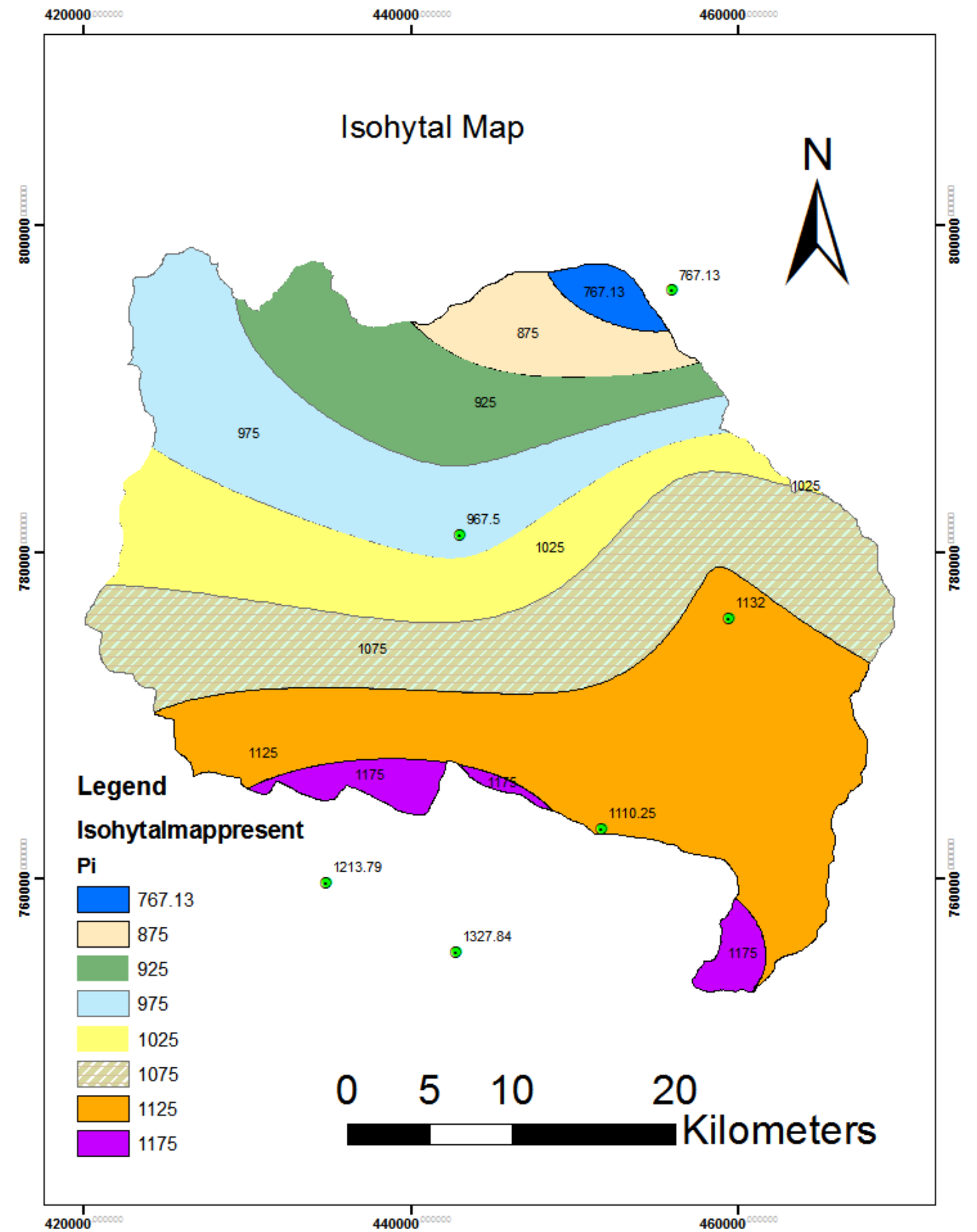

Figure 9. Isohytal map of Lake Awassa catchment.

\subsubsection{Temperature}

One of the factors affecting evaporation is temperature of the evaporating surface. The rate of evaporation is dependent on the temperature at the evaporating surface and that of atmospheric air. The amount of water vapour in the atmosphere is directly related to the temperature [15]. At a given temperature air can hold a maximum amount of moisture; saturation humidity. This is directly proportional to the temperature of air.

In the study area, as in all other places of Ethiopia, the altitude of the sun is always high, making solar radiation intense. The variation in the amount of solar radiation received daily is small throughout the year. Temperature is high during the day and is considerably reduced at night causing the daily range of temperature to be large. But in the case of monthly averages, variation is minimal and the annual range of temperature is small. This holds true in both the highlands and lowlands. Slight seasonal variations in the angle of the sun's rays and the length of the day are primary controls on temperature, resulting in a yearly temperature range that is less than the daily range.

Temperature data were taken from the Awassa meteorological station for the year 1973-2010. The mean annual minimum temperature of the study area is $12.5^{\circ} \mathrm{C}$ and the mean annual maximum temperature is $26.9^{\circ} \mathrm{C}$. The mean annual air temperature of the area is $19.7^{\circ} \mathrm{C}$. The lowest mean monthly temperature $18.8^{\circ} \mathrm{C}$ and $18.9^{\circ} \mathrm{C}$ is recorded in December and November respectively and the highest mean monthly temperature is recorded in 
$\operatorname{March} 21.1^{\circ} \mathrm{C}$

Table 6. Mean monthly temperature $\left({ }^{\circ} \mathrm{C}\right)$ at Awassa station (1973-2010).

\begin{tabular}{|c|c|c|c|c|c|c|c|c|c|c|c|c|}
\hline Months & Jan & $\mathrm{Feb}$ & Mar & Apr & May & Jun & Jul & Aug & $\mathrm{Sep}$ & Oct & Nov & Dec \\
\hline $\begin{array}{l}\text { Mean monthly maximum } \\
\text { temperature }\end{array}$ & 28.5 & 29.4 & 29.4 & 28.1 & 26.8 & 25.3 & 24 & 24.4 & 25.2 & 26.6 & 27.7 & 27.9 \\
\hline $\begin{array}{l}\text { Mean monthly minimum } \\
\text { temperature }\end{array}$ & 10.8 & 11.7 & 12.7 & 13.8 & 13.9 & 14.1 & 14.2 & 14 & 13.3 & 12.1 & 9.7 & 9.6 \\
\hline $\begin{array}{l}\text { Mean } \\
\text { temperature }\end{array}$ & 19.7 & 20.6 & 21.1 & 20.9 & 20.4 & 20.2 & 19.1 & 19.7 & 19.3 & 19.3 & 18.9 & 18.8 \\
\hline
\end{tabular}

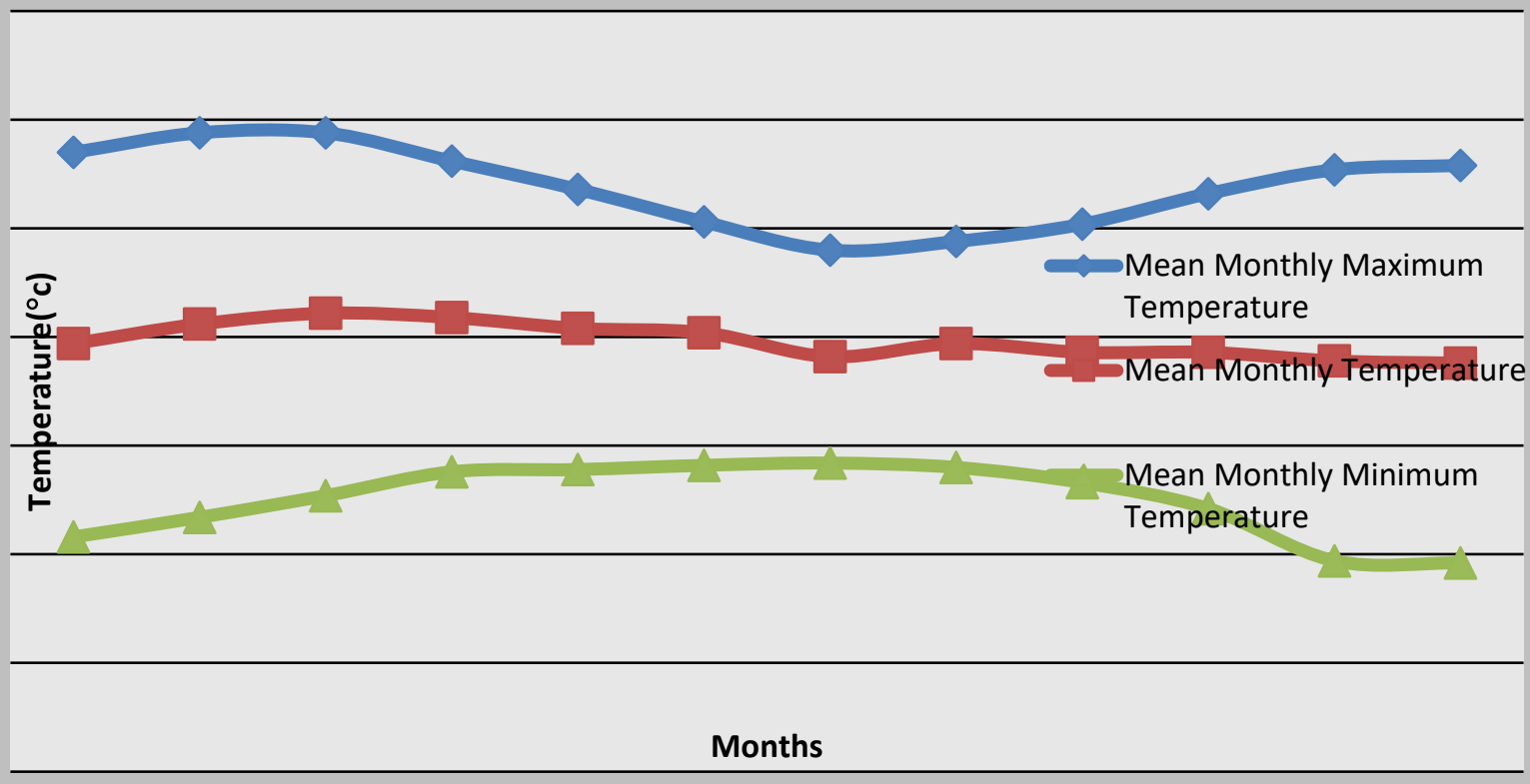

\subsubsection{Relative Humidity}

Figure 10. Mean temperature $\left({ }^{\circ} \mathrm{C}\right)$ at Awassa station ( $\left.1973-2010\right)$.

It is the relative measure of the amount of moisture in the air to the amount needed to saturate the air at the same temperature. It indirectly governs the rate of evaporation; higher values indicate that the air is nearer to saturation point, and lower values that the air consists fewer water vapour in the atmosphere.

The relative humidity data (\%) was taken from Awassa meteorological station. The data was recorded from 1991 to 2010. The maximum and minimum relative humidity value is found in September (72.84\%) and February $(50.22 \%)$, respectively. This maximum and minimum value is also within very highly rainy month and dry month, respectively. In general the highest humidity values are found in the rainy months whereas the lowest values are in dry months.

Table 7. Mean monthly relative humidity (\%) at Awassa station (1991-2010).

\begin{tabular}{lllllllllllll}
\hline Months & Jan & Feb & Mar & Apr & May & Jun & Jul & Aug & Sept & Oct & Nov & Dec \\
\hline $\begin{array}{l}\text { Mean } \\
\text { monthly }\end{array}$ & 53.21 & 50.22 & 55.9 & 64.82 & 69.2 & 69.19 & 72.45 & 72.32 & 72.84 & 65.45 & 53.82 & 52.53 \\
relative & & & & & & & & & & & & \\
$\begin{array}{l}\text { humidity } \\
(\%)\end{array}$ & & & & & & & & & & & & \\
\hline
\end{tabular}




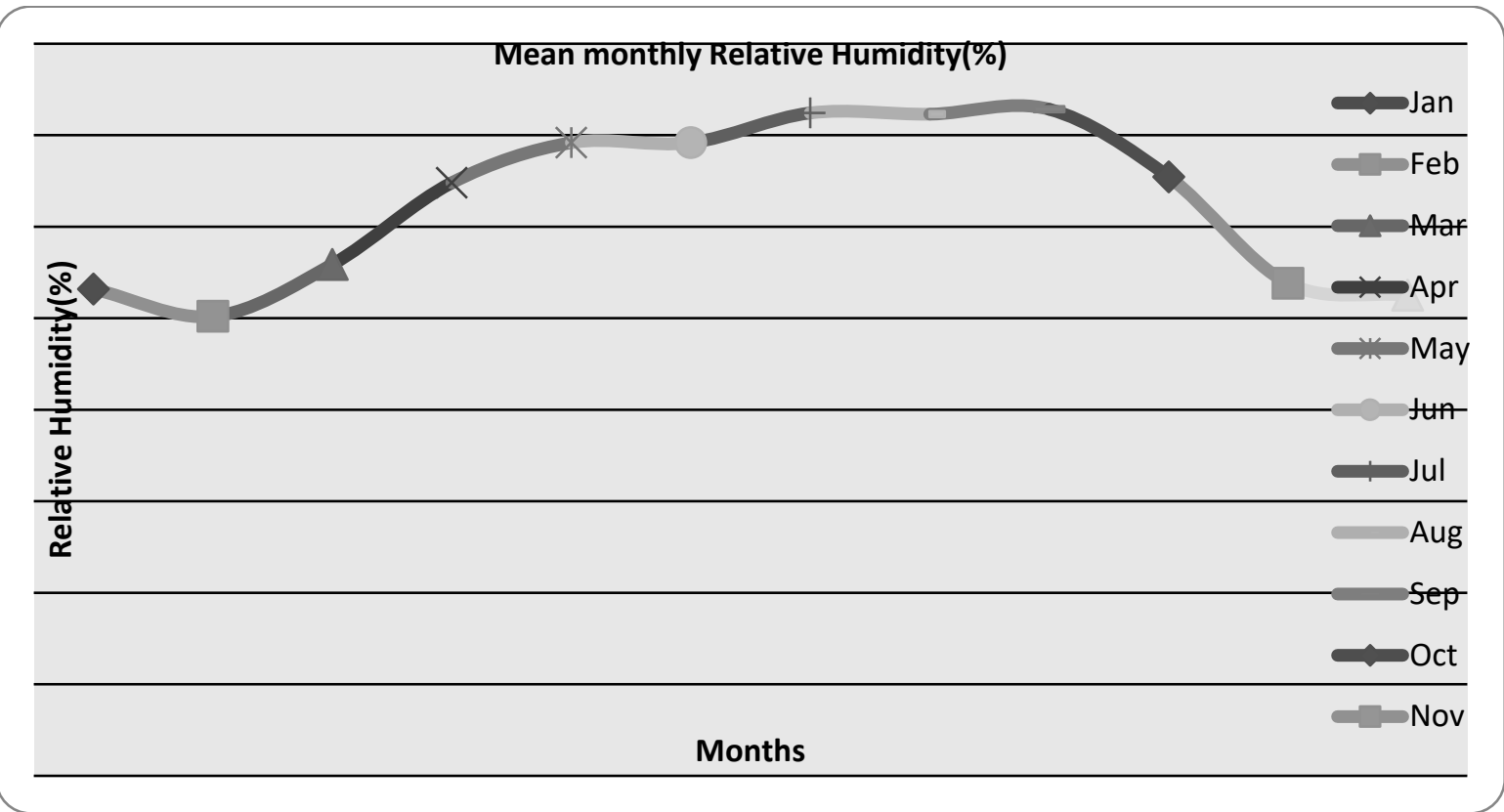

\subsubsection{Sunshine Hours}

Figure 11. Mean monthly relative humidity (\%) at Awassa station (1991-2010).

Solar energy is the major input of energy for evaporation to take place. Thus, sunshine hours play significant role in controlling the rate of evaporation.

Monthly sunshine hours were collected from Awassa meteorological station. The data was recorded from 1986 to 2010. The maximum sunshine hour is recorded in December ( 9.22 hours) and November ( 9.1 hours) whereas the minimum one is in July (4.87 hours) and August (5.4 hours). Generally, the maximum sunshine hours are found in dry months whereas the minimum are in very highly rainy months.

Table 8. Mean monthly sunshine hours at Awassa station (1986-2010).

\begin{tabular}{lllllllllllll}
\hline Months & Jan & Feb & Mar & Apr & May & Jun & Jul & Aug & Sep & Oct & Nov & Dec \\
\hline $\begin{array}{l}\text { Mean } \\
\text { monthly }\end{array}$ & 8.80 & 8.52 & 7.91 & 6.79 & 7.41 & 6.66 & 4.87 & 5.4 & 5.82 & 6.79 & 9.1 & 9.22 \\
$\begin{array}{l}\text { sunshine } \\
\text { hours }\end{array}$ & & & & & & & & & & & & \\
\hline
\end{tabular}

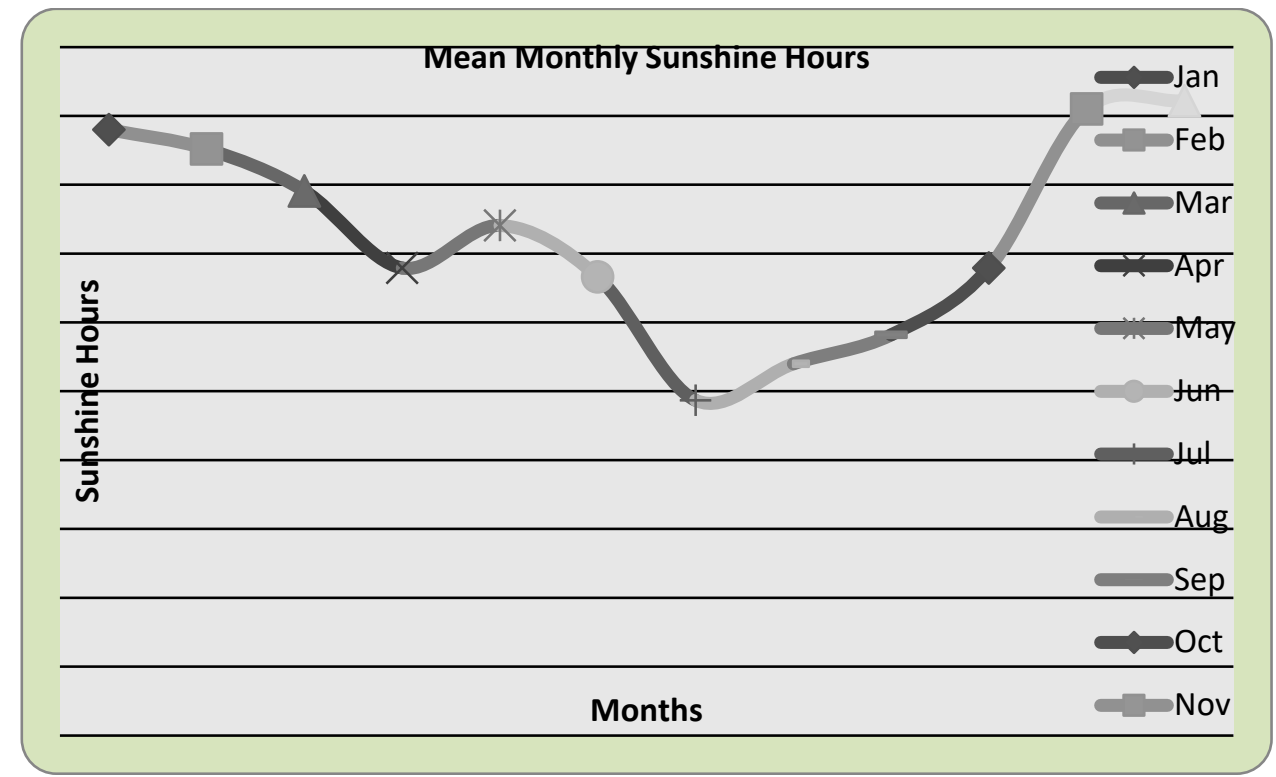

\subsubsection{Wind Speed}

Figure 12. Mean monthly sun shine hours at Awassa station (1986-2010).

The station at Awassa has been measuring wind speed with Anemometer at $2 \mathrm{~m}$ above ground surface, since 1973.

Decrease in wind speed results in decrease of evaporation rate, as the vapor-saturated air is not removed 
instantaneously. Hence evaporation rate should always be considered together with wind speed.

The maximum and minimum wind speed value is obtained in June $(1.19 \mathrm{~m} / \mathrm{s})$ and October $(0.73 \mathrm{~m} / \mathrm{s})$, respectively. Table 9. Mean monthly wind speed (m/s) at 2 meters height at Awassa station (1973-2010).

\begin{tabular}{lllllllllllll}
\hline Months & Jan & Feb & Mar & Apr & May & Jun & Jul & Aug & Sept & Oct & Nov & Dec \\
\hline $\begin{array}{l}\text { Mean } \\
\text { monthly wind } \\
\text { speed (m/s) }\end{array}$ & 1.05 & 1.06 & 1.03 & 0.99 & 1.05 & 1.19 & 1.06 & 0.94 & 0.83 & 0.73 & 0.82 & 0.95 \\
\hline
\end{tabular}

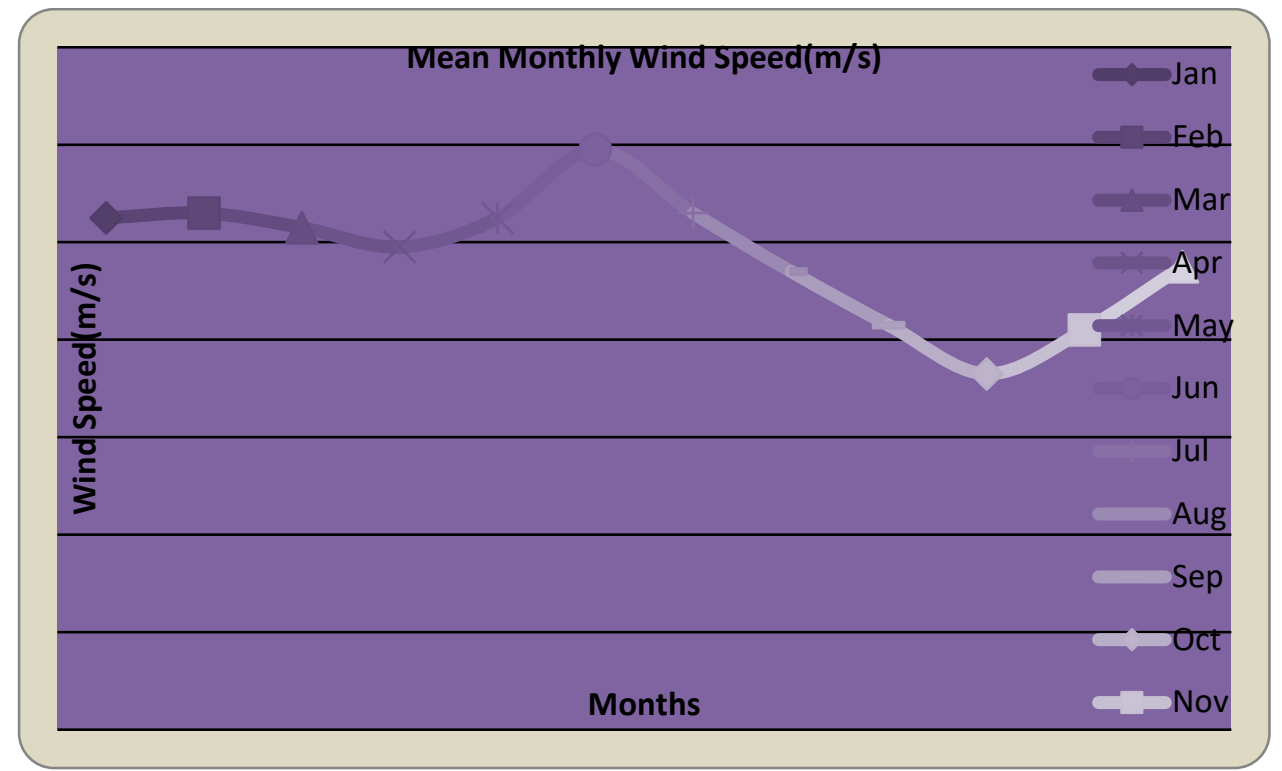

\subsubsection{Evaporation from the Lakes}

Figure 13. Mean monthly wind speed ( m/s) at Awassa station (1973-2010).

The two main factors influencing evaporation from an open water surface are the supply of energy to provide the latent heat of vaporization and the ability to transport the vapor away from the evaporative surface. Solar radiation is the main source of heat energy. The ability to transport vapor away from the evaporative surface depends on the wind velocity over the surface and the specific humidity gradient in the air above it. Among the meteorological stations within and around Awassa catchment, only that of Awassa has evaporation data which is pan evaporation of class-A type and the data are recorded on monthly basis.

Direct measurement of evaporation or evapotranspiration from extensive water or land surface has not yet been realized. In order to incorporate evaporation component in lake water balance computations, it is necessary to convert the pan evaporation data into open water surface evaporation.

The available measured pan evaporation from class 'A' pan for the period 1986-2008 has been used for computing open water evaporation or lake water evaporation. Long term pan evaporation data at Awassa station, using class A pan, is used to show the highest evaporation in dry month and least in summer time.

The pan evaporation is usually higher than the lake or reservoir evaporation because it receives radiation both from side and beneath. Thus a pan coefficient is used to correct the pan evaporation data to lake evaporation. Detailed studies in the United States Midwest for class A pan suggested an annual value of 0.75 coefficient (Roberts \& Stall, 1967). The mean annual pan evaporation is computed to be $1986.8 \mathrm{~mm}$ and Pan coefficient of 0.75 is used for correction and result in $1490.1 \mathrm{~mm}$ of mean annual lake evaporation at Lake Awassa.

Table 10. Monthly pan evaporation (mm) (1986-2008).

\begin{tabular}{lllllllllllll}
\hline Month & Jan & Feb & Mar & Apr & May & Jun & Jul & Aug & Sep & Oct & Nov & Dec \\
\hline Evaporation (mm) & 192 & 204 & 193 & 167.6 & 165 & 156.8 & 132 & 137 & 133 & 151.7 & 174 & 180.7
\end{tabular}




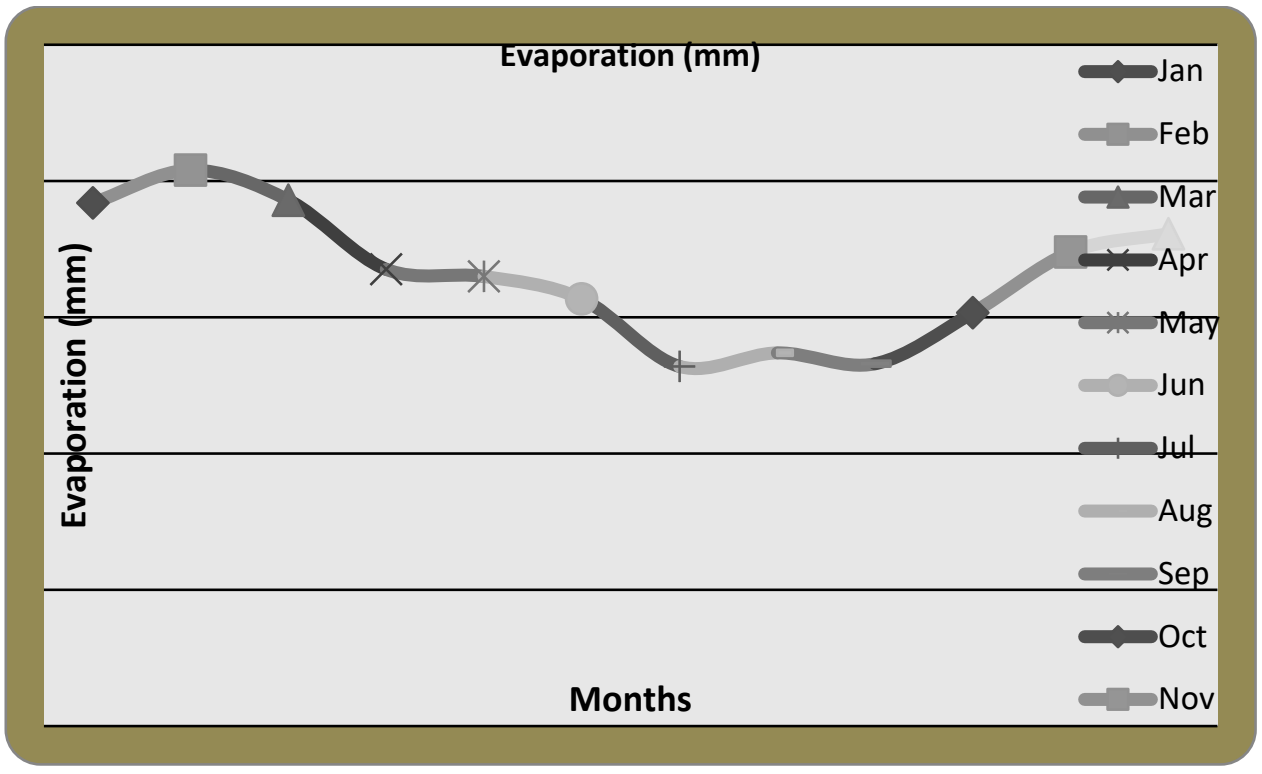

Figure 14. Monthly pan evaporation (mm) (1986-2008)

\subsubsection{Potential Evapotranspiration}

The evaporation plus transpiration from a vegetated surface with unlimited water supply is known as potential evapotranspiration (PET) and it constitutes the maximum possible loss rate due to the prevailing meteorological conditions. Potential evapotranspiration or PET is a measure of the ability of the atmosphere to remove water from the surface through the processes of evaporation and transpiration assuming no control on water supply.

Evapotranspiration is that portion of the precipitation which returns back to the atmosphere through evaporation from a free water surface, a bare soil or interception on a vegetal cover and other objects and transpiration from plants. In this study an attempt was made to estimate both potential evapotranspiration and actual evapotranspiration for the catchment. The Thornthwaite method was used to estimate the potential evapotranspiration of the basin. Potential evapotranspiration rates calculated for the station employed in this study is given in Table 11. Monthly variation of potential evapotranspiration at a station also indicates variation in monthly air temperatures, since potential evapotranspiration is calculated basically from temperature data. Based on this method the mean annual potential evapotranspiration of the catchment is $892.35 \mathrm{~mm}$.

Table 11. Potential evapotranspiration at Awassa catchment.

\begin{tabular}{|c|c|c|c|c|c|c|c|c|c|c|c|c|c|}
\hline Months & Jan & $F e b$ & Mar & $A p r$ & May & Jun & Jul & Aug & $\mathrm{Sep}$ & Oct & Nov & $\mathrm{Dec}$ & Annual \\
\hline $\begin{array}{l}\text { Mean monthly air } \\
\text { temperature }\end{array}$ & 19.7 & 20.6 & 21.1 & 20.9 & 20.4 & 20.2 & 19.1 & 19.7 & 19.3 & 19.3 & 18.9 & 18.8 & \\
\hline $\mathrm{J}$ & 7.82 & 8.36 & 8.67 & 8.55 & 8.24 & 8.12 & 7.47 & 7.82 & 7.58 & 7.58 & 7.35 & 7.29 & 94.85 \\
\hline $\begin{array}{l}\text { Latitude correction } \\
\text { factor at } 5^{\circ} \mathrm{N}\end{array}$ & 0.98 & 0.99 & 1 & 1.02 & 1.03 & 1.03 & 1.03 & 1.03 & 1.01 & 1 & 0.99 & 0.98 & \\
\hline $\begin{array}{l}\text { Unadjusted } \\
\text { potential } \\
\text { evapotranspiration } \\
(\mathrm{mm})\end{array}$ & 72.64 & 79.68 & 83.74 & 82.1 & 78.09 & 76.51 & 68.14 & 72.64 & 69.62 & 69.62 & 66.67 & 65.94 & 885.39 \\
\hline $\begin{array}{l}\text { Corrected potential } \\
\text { evapotranspiration } \\
(\mathrm{mm})\end{array}$ & 71.19 & 78.88 & 83.74 & 83.74 & 80.43 & 78.81 & 70.18 & 74.82 & 70.32 & 69.62 & 66.00 & 64.62 & 892.35 \\
\hline
\end{tabular}

\subsubsection{Actual Evapotranspiration}

The term actual evapotranspiration is used to describe the amount of water loss that occurs under moisture deficiency, existing condition.

Due to almost complete lack of field instruments such as lysimeters, the Thornthwaite water balance model was used to estimate the actual evapotranspiration of the study area. Through the calculation of an average water balance, actual evapotranspiration was estimated for the dominant soil types and the respective land use in the area, and for the entire catchment. For each dominant soil type and respective land use, the results are summarized and are given in Tables $12 \& 13$. The actual evapotranspiration for the dominant soil types and the respective land uses in the area was weighted according to the proportion of the area they represent, and the weighted actual evapotranspiration was calculated by utilizing equation 6 to determine the actual evapotranspiration of the study area. Accordingly, the annual actual evapotranspiration of the catchment is $828.37 \mathrm{~mm}$. The actual evapotranspiration is computed from the PET, precipitation and the soil moisture availability as presented by Thorentwaite and Mather [2].The soil moisture availability is calculated from accumulated potential water loss and available water capacity. The available water capacity (AWC) has been computed from the vegetation type 
and soil type. Accordingly, the following combination of land cover and soil type, which were identified in the study area, has been used. Silty loam with cereal crops with area coverage of $416.19 \mathrm{~km}^{2}$ and with bushy and shrubs is $25.8 \mathrm{~km}^{2}$. Fine sand with bush and shrub has an area of $269.93 \mathrm{~km}^{2}$. Clay loam with cereal crop has an area coverage of $338.63 \mathrm{~km}^{2}$ and fine sandy loam with cereals has an area of $140.05 \mathrm{~km}^{2}$.

Table 12. Actual evapotranspiration for a soil with an available water capacity of $200 \mathrm{~mm}$. The soil is a clay loam in areas of farming cover by cereal crops with an average rooting depth of $80 \mathrm{~cm}$. All values in table are in millimeters.

\begin{tabular}{|c|c|c|c|c|c|c|c|c|c|c|c|c|c|}
\hline & Jan & $\mathrm{Feb}$ & Mar & $\mathrm{Apr}$ & May & Jun & Jul & Aug & Sep & Oct & Nov & $\mathrm{Dec}$ & Annual \\
\hline $\mathrm{P}_{\mathrm{m}}$ & 35.11 & 40.83 & 98.39 & 142.26 & 130.17 & 95.85 & 115.65 & 117.49 & 145.15 & 105.42 & 36.15 & 23.96 & 1086.43 \\
\hline CPET & 71.19 & 78.88 & 83.74 & 83.74 & 80.43 & 78.81 & 70.18 & 74.82 & 70.32 & 69.62 & 66.00 & 64.62 & 892.35 \\
\hline P-PET & -36.08 & -38.05 & 14.65 & 58.52 & 49.74 & 17.04 & 45.47 & 42.67 & 74.83 & 35.8 & -29.85 & -40.66 & \\
\hline Acc.Pot.WL & -106.59 & -144.64 & & & & & & & & & -29.85 & -70.51 & \\
\hline SM & 115 & 92 & 97 & 200 & 200 & 200 & 200 & 200 & 200 & 200 & 200 & 166 & \\
\hline$\Delta \mathrm{SM}$ & -51 & -23 & 5 & 103 & 0 & 0 & 0 & 0 & 0 & 0 & 0 & -34 & \\
\hline AET & 86.11 & 63.83 & 83.74 & 83.74 & 80.43 & 78.81 & 70.18 & 74.82 & 70.32 & 69.62 & 36.15 & 57.96 & 855.71 \\
\hline
\end{tabular}

$\mathrm{P}_{\mathrm{m}}=$ Mean Monthly Precipitation; CPET $=$ Corrected Potential Evapotranspiration;

$\mathrm{P}-\mathrm{CPET}=$ is Difference by Subtraction; Acc. Pot.WL = Accumulated Potential Water Loss; $\mathrm{SM}=$ Soil Moisture; $\Delta \mathrm{SM}=$ Change in Soil Moisture during the Month; AET $=$ Actual Evapotranspiration.

Table 13. Estimated actual evapotranspiration for the different land use and soil type combinations.

\begin{tabular}{|c|c|c|c|c|c|c|c|c|c|c|c|c|c|}
\hline Month & Jan & $\mathrm{Feb}$ & Mar & $\mathrm{Apr}$ & May & Jun & Jul & Aug & Sep & Oct & Nov & $D e c$ & Annual \\
\hline $\begin{array}{l}\text { AET } \\
\text { for } \\
\text { AWC } \\
\text { of } 100\end{array}$ & 50.11 & 51.83 & 83.74 & 83.74 & 80.43 & 78.81 & 70.18 & 74.82 & 70.32 & 69.62 & 62.15 & 48.96 & 824.71 \\
\hline $\begin{array}{l}\text { AET } \\
\text { for } \\
\text { AWC } \\
\text { of } 150\end{array}$ & 55.11 & 56.83 & 83.74 & 83.74 & 80.43 & 78.81 & 70.18 & 74.82 & 70.32 & 69.62 & 63.15 & 53.96 & 840.71 \\
\hline $\begin{array}{l}\text { AET } \\
\text { for } \\
\text { AWC } \\
\text { of } 200\end{array}$ & 86.11 & 63.83 & 83.74 & 83.74 & 80.43 & 78.81 & 70.18 & 74.82 & 70.32 & 69.62 & 36.15 & 57.96 & 855.71 \\
\hline $\begin{array}{l}\text { AET } \\
\text { for } \\
\text { AWC } \\
\text { of } 250\end{array}$ & 60.11 & 63.83 & 83.74 & 83.74 & 80.43 & 78.81 & 70.18 & 74.82 & 70.32 & 69.62 & 64.15 & 57.96 & 857.71 \\
\hline
\end{tabular}

\subsubsection{Runoff}

\subsubsection{Tikurwoha River}

The catchment area of Tikurwoha river is $625 \mathrm{~km}^{2}$ that is $45.7 \%$ of the lake catchment area. Tikurwoha river is the only perennial and gauged stream, which flows into lake Awassa. It has been gauged since 1980 at a station called Dato. The data from this station is used for interpretations. Accordingly, the mean annual discharge is 84.17 MCM.

Table 14. Mean discharge of Tikurwoha river (MCM) at Dato gauging station (1980-2006).

\begin{tabular}{llllllllllllll}
\hline Months & Jan & Feb & Mar & Apr & May & Jun & Jul & Aug & Sep & Oct & Nov & Dec & Annual \\
\hline $\begin{array}{l}\text { Mean river } \\
\text { discharge }\end{array}$ & 5.81 & 4.59 & 4.75 & 4.75 & 6.21 & 7.24 & 7.62 & 8.44 & 9.27 & 10.16 & 8.14 & 7.19 & 84.17 \\
(MCM) & & & & & & & & & & & & & \\
\hline
\end{tabular}




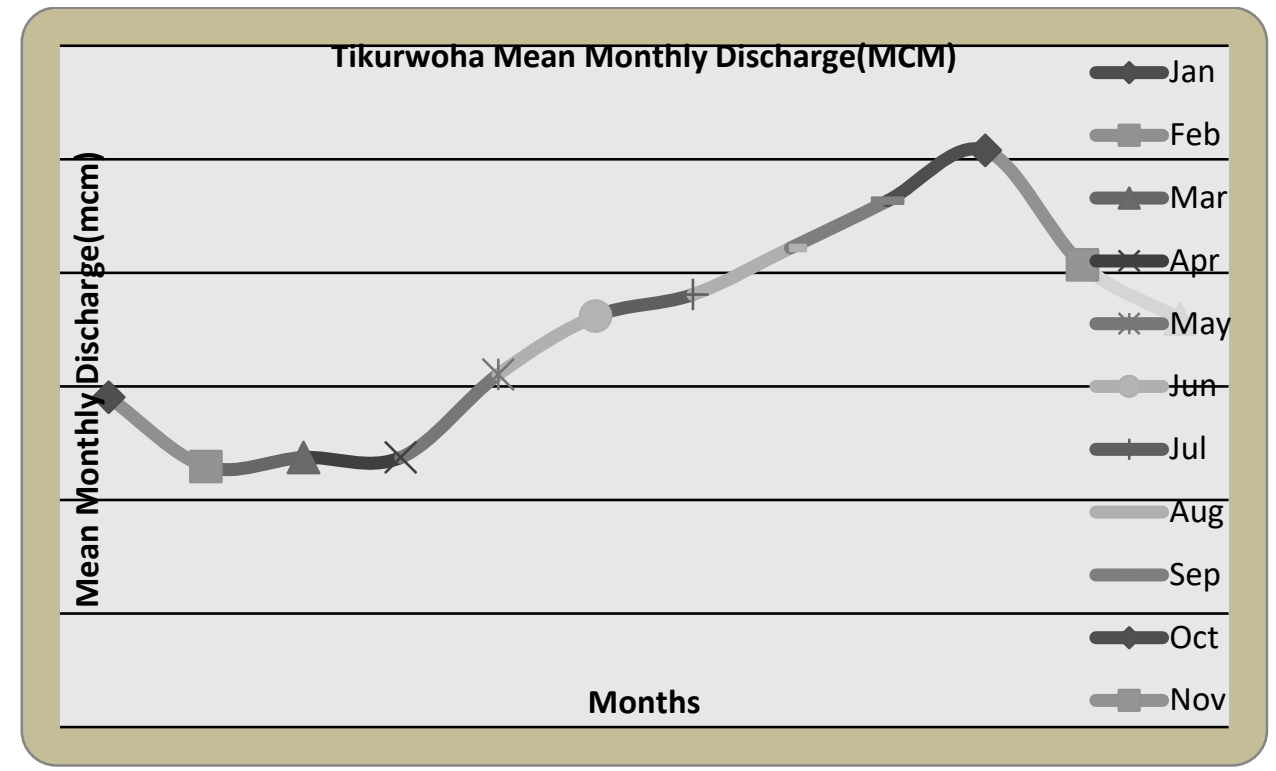

\subsubsection{Un-gauged Runoff}

Figure 15. Mean monthly discharge (MCM) of Tikurwoha river (1980-2006).

The runoff carried by seasonal streams and gullies has not been gauged. The runoff for the un-gauged catchment is computed using Eq. 7.

The runoff coefficient was estimated from rainfall- runoff relation in Tikurwoha catchment [8]:

Runoff coefficient $(\mathrm{RC})=$ Annual discharge of Tikurwoha $/$ Rainfall volume in the catchment $=84.17 \mathrm{MCM} / 649.9$ $\mathrm{MCM}=0.13$

In order to estimate concentrated flow carried by these intermittent channels and diffused flow, runoff coefficient of 0.13 was used.

The area drained by the ungauged channels is $621 \mathrm{~km}^{2}$. The mean annual rainfall over the catchment is 1039.85 $\mathrm{mm}$. Accordingly, the mean annual runoff generated from the un-gauged catchment is estimated to be 83.95 million cubic meters.

\subsection{Water Balance}

The water balance is an accounting of the inputs and outputs of water [17]. The water balance represents the hydrological gains and losses of a given system (reservoir, column of soil, aquifer, river basin, etc) over a specific period. The water balance is sometimes referred as water budget. Hydrologic budget is a quantitative evaluation of the total water gained or lost from a given hydrological system during a specific period of time. In this study an attempt was made to make a water balance for both catchment and the lake.

\subsubsection{Lake Water Balance}

The mean annual lake evaporation at lake Awassa is $1490.1 \mathrm{~mm}$, whereas mean annual rainfall in Awassa station is $967.5 \mathrm{~mm}$ per year. The lake surface, on the average, receives about $92.88 \mathrm{MCM}$ of water annually from direct rainfall on its surface. The mean annual discharge of Tikurwoha river is $84.17 \mathrm{MCM}$. Runoff from ungauged catchment is $83.95 \mathrm{MCM}$, making the total runoff $168.12 \mathrm{MCM}$ and rate of lake evaporation, on the average, is about 143.05 MCM. Outflow from the lake, in the form of groundwater discharge, is about $71.5 \mathrm{MCM} / \mathrm{year}$ on average condition [10].

The water balance of the lake is equated according to the following mass balance equation:

Input $=$ out put $\pm \Delta \mathrm{S}$ where, $\Delta \mathrm{S}$ is change in storage.

Where input $=$ Direct rainfall on the lake surface + Surface runoff from ungauged catchment + discharge from Tikurwoha river

$=92.88 \mathrm{MCM}+83.95 \mathrm{MCM}+84.17 \mathrm{MCM}=261 \mathrm{MCM}$ per year

Out put $=$ Evaporation + Groundwater outflow

$$
=143.05 \mathrm{MCM}+71.5 \mathrm{MCM}=214.55 \mathrm{MCM} \text { per year }
$$

Change in storage $(\Delta \mathrm{S})=$ Input - output

$$
\begin{aligned}
\Delta \mathrm{S}= & 261 \mathrm{MCM}-214.55 \mathrm{MCM} \\
& =46.45 \mathrm{MCM} \text { per year. }
\end{aligned}
$$

Therefore, from the above annual lake water balance analysis, it can be concluded that Awassa lake level has been increasing. Besides, it indicates that there is more inflow to the lake compared with outflow in the form of evaporation. 


\subsubsection{Water Balance of the Catchment}

In the study area the water balance is used for the estimation of the natural ground water recharge of the catchment. The general water balance equation for the catchment is given by Inflow $=$ Out flow $\pm \Delta S$ where, $\Delta \mathrm{S}$ is change in storage.

The following assumptions are made to derive the water balance equation of the study area:

- $\quad$ The surface water divide and groundwater divide coincides.

- The water balance is on annual basis, which means change in storage assumed to be zero.

- There is no groundwater inflow from the neighboring basin.

- The annual groundwater outflow from the catchment to adjacent basins is estimated to be $52.5 \times 10^{6} \mathrm{~m}^{3}$ [5] using groundwater flow modeling.

Since the basin is a closed basin the main outflow pathway of the water that comes in the form of rain is mainly through evapotranspiration. Consequently, the water balance equation for the study area is written as follows:

$\mathrm{P}=\mathrm{AET}+\mathrm{I}$

Where, $\mathrm{P}=$ Precipitation

$\mathrm{AET}=$ Actual evapotranspiration; and, I=Infiltration/Groundwater recharge.

From the above budget equation the amount of water that infiltrates in to the catchment area as a ground water accretion has been calculated as follows.

$\mathrm{P}=1039.85 \mathrm{~mm}$, and $\mathrm{AET}=828.37 \mathrm{~mm}$.

$\mathrm{I}=\mathrm{P}-\mathrm{AET}$

$\mathrm{I}=1039.85 \mathrm{~mm}-828.37 \mathrm{~mm}$

$\mathrm{I}=211.48 \mathrm{~mm}$

In terms of water volume measured in cubic meter, I is expressed as:

Area of the catchment $=1367 \times 10^{6} \mathrm{~m}^{2}$

Therefore,

$\mathrm{I}=289.09 \times 10^{6} \mathrm{~m}^{3}$

Annual discharge of groundwater from boreholes, shallow wells, springs and hund dug wells for domestic and non domestic uses in the catchment is $17.8 \times 10^{6} \mathrm{~m}^{3}$. The annual groundwater outflow from the catchment to adjacent basins is estimated to be $52.5 \times 10^{6} \mathrm{~m}^{3}$ [5] Therefore, the net amount of water that infiltrates into the ground, In, is given by:

$\mathrm{In}=\mathrm{I}-(52.5+17.8) \times 10^{6} \mathrm{~m}^{3}=\mathrm{I}-70.3 \times 10^{6} \mathrm{~m}^{3}$

$\mathrm{In}=289.09 \times 10^{6} \mathrm{~m}^{3}-70.3 \times 10^{6} \mathrm{~m}^{3}=218.79 \times 10^{6} \mathrm{~m}^{3}$

Based on the above calculation, therefore, it is possible to say that the net total amount of water which is actually available to recharge the groundwater circulation within the Lake Awassa catchment is 218.79 million cubic meter. The average change in surface water storage was assumed to be zero, but in general this is not the case in Lake Awassa catchment in which the lake level is seen to increase though not linearly. The average annual increment of the lake level is insignificant as compared to water recharge in the basin.

\subsection{Current Groundwater Development Activity}

According to the survey conducted in the study area, groundwater is mainly used for domestic and industrial purposes. Inventory of groundwater structures that was held in this study indicates that there are about 233 different types of groundwater structures found in difffernt parts of the study area. These structures are deep boreholes, shallow wells, hand dug wells and developed springs. The majority of these structures are developed by governmental and nongovernmental organizations whereas few of them were developed privately by the dwellers in the catchment.

Table 15. Groundwater structures in the study area.

\begin{tabular}{lrc}
\hline Types of Structures & Total Number & Percentage (\%) \\
\hline Boreholes & 48 & 20.6 \\
Shallow wells & 60 & 25.75 \\
Hand dug wells & 44 & 18.89 \\
Spring & 81 & 34.76 \\
Total Number & 233 & 100 \\
\hline
\end{tabular}




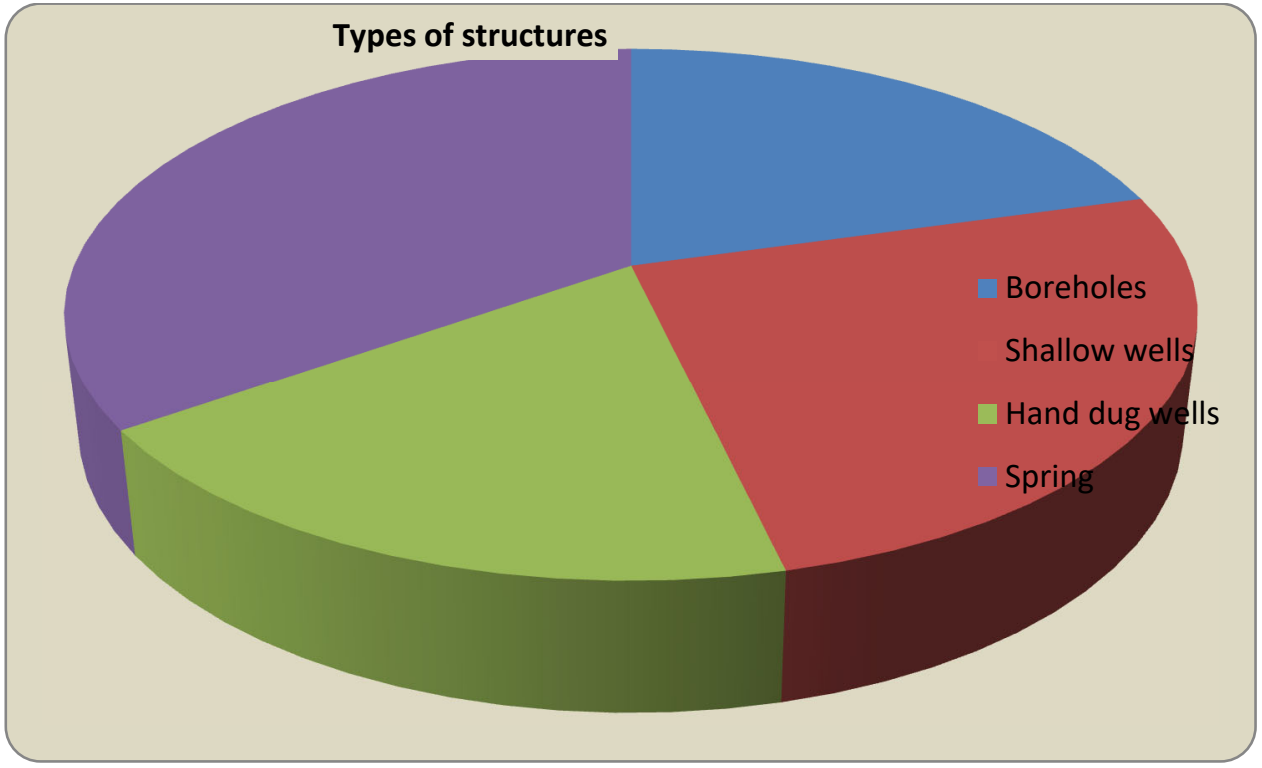

Figure 16. Different types of groundwater structures in Lake Awassa catchment.

Scientific development of groundwater involves a proper understanding of the local groundwater availability with scientific planning. It is necessary to study, identify and evaluate the water resources of the basin and develop an exploitation strategy that best suites the basin. However, this is not the case in the study area. Even though the above mentioned numbers of groundwater structures are found developed in the study area, however, according to the interview conducted with hydrogeologists and leaders of water resources development offices, the development of each of them was not based on earlier conducted investigation of groundwater in the catchment. Their development takes place without the knowledge of the groundwater potential of the area. Groundwater investigation for development is mainly concerned with simply locating well sites for groundwater supplies to give relief.

In Lake Awassa catchment, a number of groundwater resource potential investigations were done by different scholars. Keeping the scale and quality of these investigations in to mind, however, these investigations were not in any scale compiled and used for groundwater development activities in the catchment by responsible organizations.

\subsection{Groundwater Utilization}

As it was mentioned above 233 different types groundwater structures are found developed in different parts of the study area. However, utilization of groundwater from these structures is not conducted on the basis of recommended values that were set based on the hydrogeological parameters during the development of the structures. According to information obtained during the field survey, the structures are pumped continuously for long period of time to satisfy the water demand of the different users. Pumping and recovery hours for these different structures are not monitored properly.

Table 16. Groundwater utilization trend in some groundwater structures

\begin{tabular}{lllll}
\hline Structures & Discharge $(l / s)$ & $\begin{array}{l}\text { Recommended pumping } \\
\text { during development (hours) }\end{array}$ & hours & Current pumping hours \\
\hline $\begin{array}{l}\text { Treatment } \\
\text { compound well }\end{array}$ & 7.7 & 16 & 20 \\
Mette 1 & 12.8 & 16 & 20 \\
Mette 2 & 7.3 & 16 & 20 \\
Abela Wondo 2 & 7 & 16 & 20 \\
Abela Wondo 3 & 6 & 16 & 20 \\
Gara Rikata 1 & 30 & 16 & 20 \\
\hline
\end{tabular}

This study reveals that utilization of groundwater resources, which is developed in the above mentioned way, is not also supported by designed and planned manner.

\subsection{Status of Groundwater Structures}

Provision of adequate water supply services for urban and rural populations are the major issues in the study area. A total of 63 and 170 water supply schemes were inventoried in the urban and rural areas of the study area, respectively. In urban areas most of the water sources are boreholes (54\%), shallow wells (35\%) and springs (11\%) whereas in rural areas springs $(44.7 \%)$, hand dug wells $(25.3 \%)$ and shallow wells $(22.9 \%)$ are the main sources. 
In general, in the study area, boreholes, shallow wells, hand dug wells and springs comprises of $20.6 \%, 25.75 \%$, $18.89 \%$ and $34.76 \%$ of the total groundwater structures, respectively.

Out of the 233 groundwater structures that are found developed in different parts of the study area, 184 of them are functional whereas the remaining 49 were non functional. Functional and non functional schemes constitute $78.97 \%$ and $21.03 \%$, respectively, of the total water supply schemes available in the areas of the catchment. Large numbers of nonfunctional groundwater structures are found in rural areas than urban areas.

Among the developed groundwater structures dominantly nonfunctional is hand dug wells, which comprises $29.55 \%$ of the total constructed hand dug wells. The hand dug wells are followed by shallow wells $(25 \%)$, springs (19.75) and boreholes (10\%).

Table 17. Current status of groundwater structures.

\begin{tabular}{|c|c|c|c|}
\hline \multirow[t]{2}{*}{ Groundwater structures } & \multicolumn{2}{|c|}{ Current Status } & Percentage of the nonfunctional \\
\hline & Functional & Nonfunctional & structures \\
\hline Hand dug wells & 31 & 13 & 29.55 \\
\hline Shallow wells & 45 & 15 & 25.00 \\
\hline Springs & 65 & 16 & 19.75 \\
\hline Boreholes & 43 & 5 & 10.42 \\
\hline
\end{tabular}

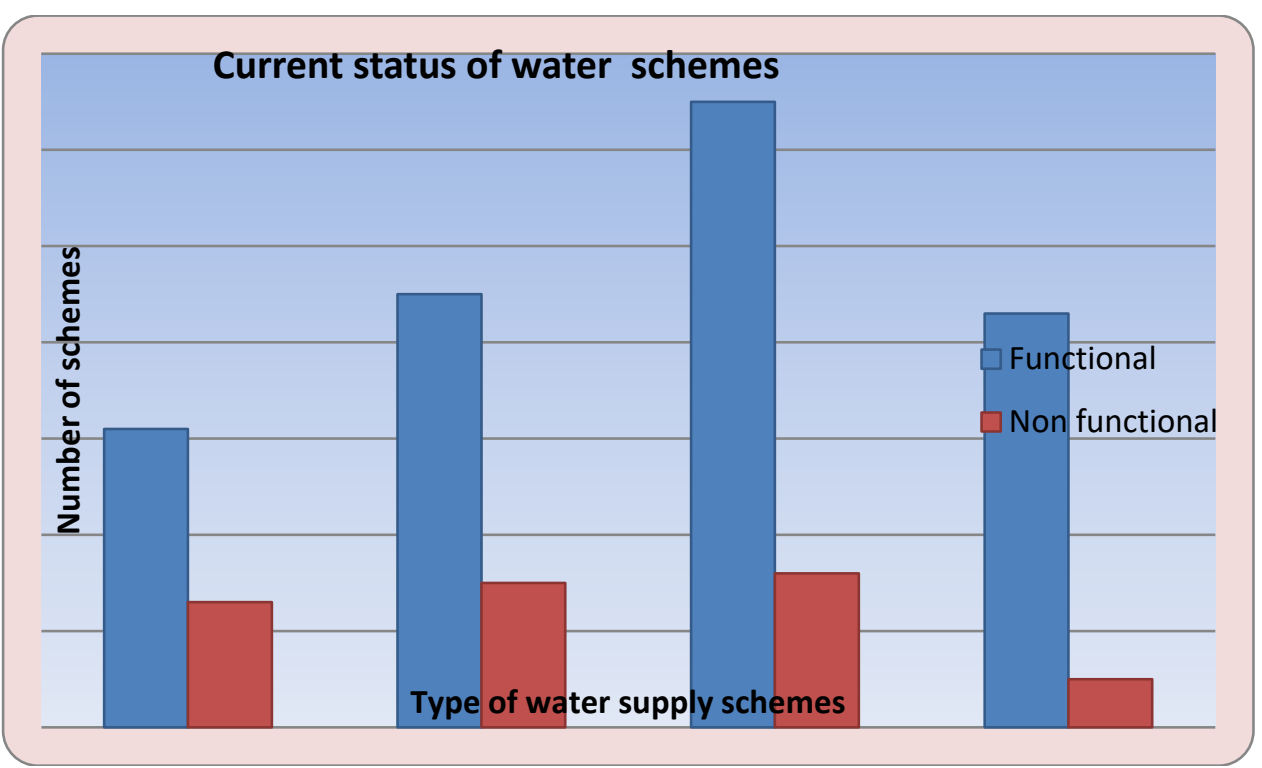

Figure 17. Current status of groundwater structures in Lake Awassa catchment.

As it is depicted in the table above, a significant number of the water supply schemes are nonfunctional. This is a serious problem to be taken in to consideration concerning the water supply coverage of the area. Poor management of the constructed schemes, lack of awareness at community level, spare part problems, and construction problems are the major causes of the failure of the groundwater structures in the studied area. 


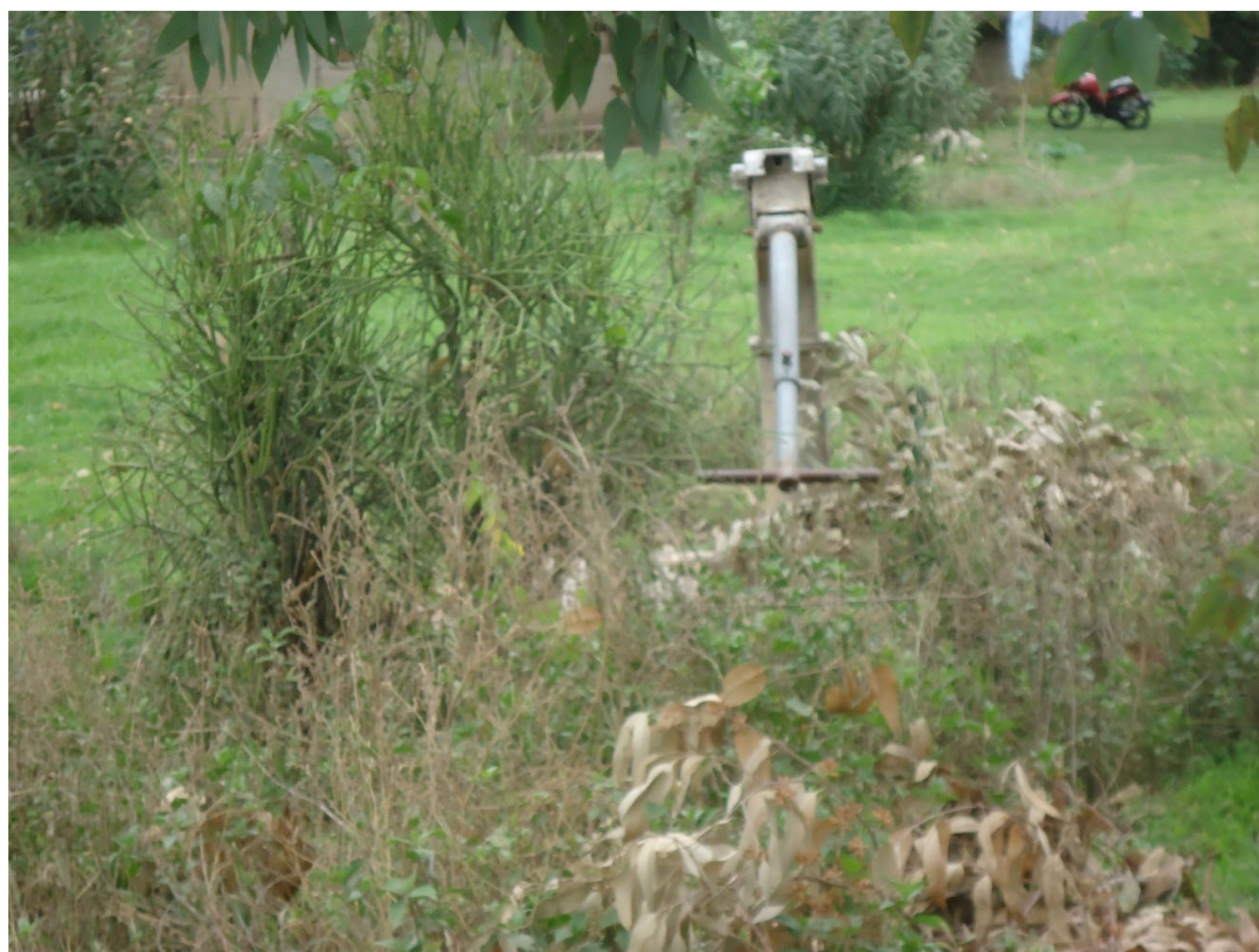

Figure 18. Non-functional shallow well, Dorebafana, near Mekane Eyesus Church.

\subsection{Groundwater Management Practices}

In most cases, in Ethiopia, the demand for water exceeds the supply from various sources such as surface water and groundwater. This is not due to lack of water resources but due to improper water resources utilization practices [16]. Meaningful planning to utilize and conserve water resources in any area should be based on the assessment of its available water resources.

Groundwater resources should be utilized in a planned manner to avoid any undesirable effects. Currently in the investigated area, groundwater management studies have not yet been conducted and used for practical purposes. Even though abstraction control through legislation is usually essential, there is no licensing control.

In the studied area, according to the interview conducted with the hydrogeologists and leaders of Water Resource Bureau indicates that development of water supplies from groundwater began typically with a few pumping wells scattered here and there within the catchment. With time, more wells were drilled and the rate of extraction was also increased. Currently groundwater is developed without groundwater management plan in uncoordinated manner by governmental and nongovernmental organizations and also privately.

In the studied area the information obtained from beneficiaries indicates that, traditionally, groundwater resource has been considered as something that will naturally and always be available for human exploitation. In town areas, stress on pumping of groundwater is increasing to meet the ever-increasing demand of water for domestic and industrial uses as compared to adjoining rural areas. There are more than sixty private wells in Awassa town for domestic and non domestic purposes. During the survey of private wells, it was found that private well owners do not know the presence of Ethiopian water resource management proclamation No.197/2000 and regulation N0.115/2005. They drill and use without any permission. They have no awareness that groundwater is a resource that can be depleted. Because of scarcity of water supply from Awassa Town Water Supply and Sewerage Enterprise, majority of hotels and pensions drill their own wells and get water for sanitation purposes.

One of the important strategies for management of groundwater is regulation of groundwater development. In the studied area, according to the interview conducted with leaders of Water Bureau there is no efforts to check the over exploitation and regulation of groundwater resource. Despite the Ethiopian Water Resources Management Proclamation and Regulations, there has been little emphasis in implementing those laws. Due to this wells are drilled enormously without the knowledge of the national and regional water sectors. If this allowed continuing in the future, overexploitation of groundwater would be inevitable. 


\subsubsection{Institutions}

Formal institutions in Ethiopia are structured at Federal and Regional levels and informal institutions, like water committees, water associations etc., are locally instituted. According to the interview conducted with water bureau leaders and information obtained from water committees during field survey, informal institutions lack linkages with the formal institutions and among themselves, and this affects the information flow and their effective involvement in water management.

In the study area water related organizational arrangements are broadly categorized into different tier: Federal (National) level and Regional (State) and local level organizations (Zonal and Woreda). The institutions are in administrative wise but there is no responsible institution in the study area at basin and sub-basin level. But there is agreement among many that water should be managed within natural hydrological units - the river basin, Lake basin or aquifer. Since, geographic situations are diverse and natural units seldom coincide with administrative units. The management of water resources at the national level is carried out by the Ministry of Water, Irrigation and Electricity. It is responsible for formulating policies for the water sectors at national level, for long term planning strategies, and for the coordination of projects. It is also responsible for legislation with regard to utilization and protection of water resources as well as the allocation of water between regional governments.

Regional states and local administrative bodies, without requiring any new law for water are strictly obliged by law to implement the water policy and the water proclamation in accordance with set directives and guidelines to be provided by the Ministry of Water, Irrigation and Electricity. The management of water resources at regional level is carried out by sector institutions organized as Water,Mines and Energy development Bureau. Because of physical size of the regional state and for better administration works, the region is divided into a number of zones. Each zone is subdivided into woredas. A woreda is a small administrative sub-district.

As far as management of urban water supply services is concerned they are autonomous to plan, implement, and manage their respective water utilities or services. In towns of the study area they are institutionalized by law as water supply and sewerage service enterprises responsible to provide urban dwellers with adequate and safe water as conditions permit.

There are also water and sanitation committees responsible for the management of drinking water schemes, operation and maintenance of water supply schemes in rural areas. However, in most of the study areas its establishment is after a long period of schemes construction or else no water committee established. Although communities play an important role in water resources development and management, according to information gathered in the study area due to lack of awareness, community participation is challenging issue.

\subsubsection{Role of Women in Water Resources Development and Management}

According to the information obtained from field observation women and children are fetching water for the households in the studied area. The participation of women in the development of water scheme is a determinant factor for its sustainability. Women and children travel long distances some times taking more than one hour in areas of water scarcity, to bring water for the households.

The information obtained from the communities during field survey indicates that in the area beneficiaries particularly women, are not involved well in the initial stages of water development due to lack of awareness. At the later stage, they would be called upon to use the scheme without considering whether or not the project is the felt need of the beneficiaries; and, therefore, the sustainability of the scheme is highly affected. This is best exemplified in Wondo Genet woreda the local NGO drilled many shallow wells but they did not establish water committee, also did not hand over the water schemes both for the community and for the Woreda Water, Mines and Energy Office. Women are the ones responsible for getting water they should be encouraged to serve as operators of the system since they are the ones who suffer most if the systems fail. At the local level, water committees are being established to run water schemes and to look after the operation and maintenance of the systems. In most of the area 1 out of 5 or 2 out of 7 members of the water committees are women in order to run the schemes but in certain areas the ratio is 2 to 5 . In most of the places the combination is $80 \%$ men and $20 \%$ women but in certain area $70-60 \%$ men and $30-40 \%$ women. Women are not fairly represented in water committees but the Ethiopian Water Resources Management Policy gives the right of full involvement of women in the planning, implementation, decision-making and training; as well as empowers them to play a leading role in selfreliance initiatives. 


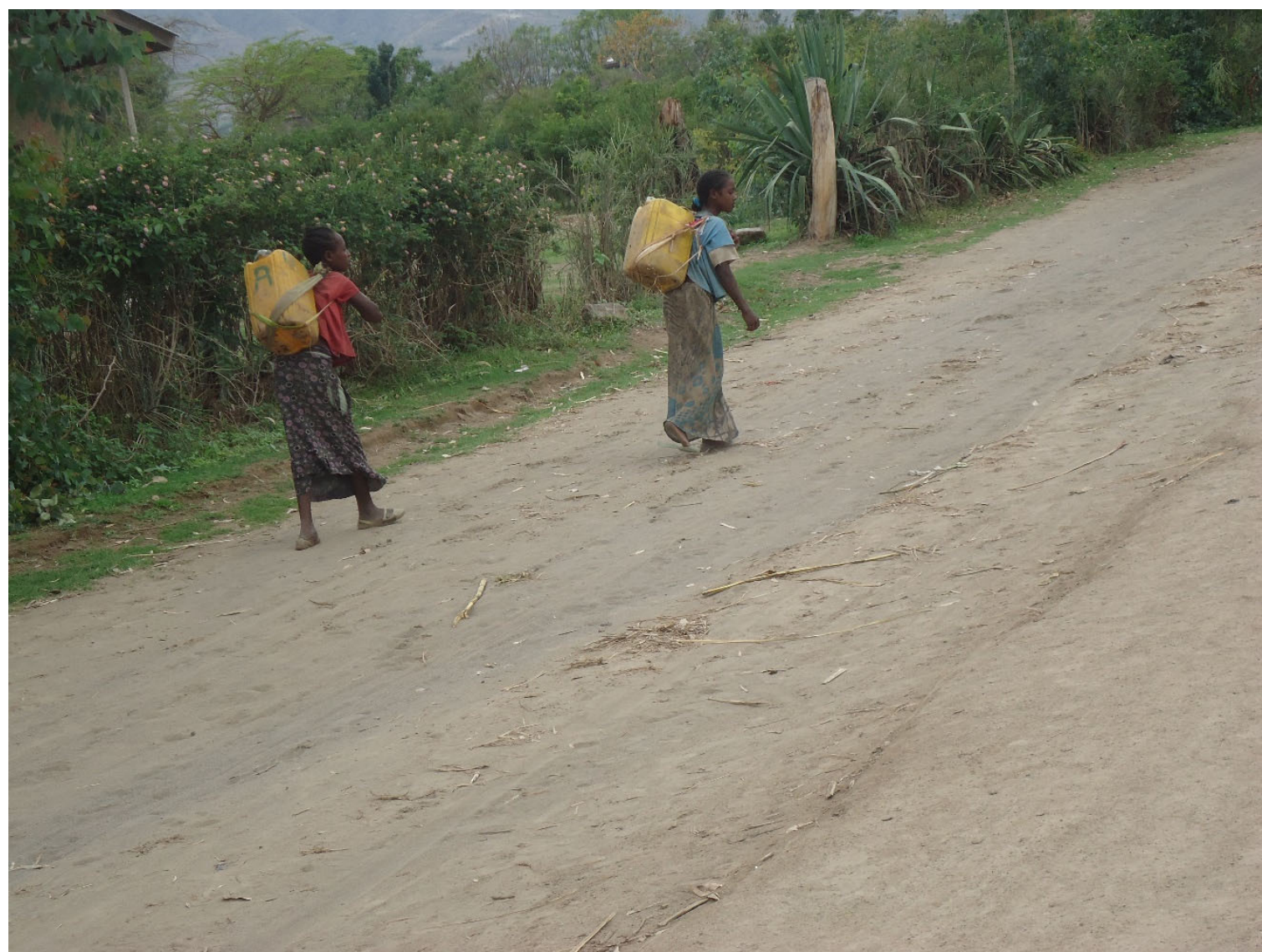

Figure 19. Girls travel long distance to fetch water.

\subsection{Gaps in Groundwater Management}

Groundwater management emphasizes that we must not only focus on development of water resources but that we must consciously manage water development in a way that ensures long term use for future generations.

Conservation and protection of water resources aim at safeguarding the resource from depletion. The depletion and degradation of water resources may be caused by several factors including deforestation which results in reduced baseflows, encroachment upon catchment areas by human settlements and agricultural production activities which accelerate sedimentation problems in lakes and river channels.

The sectoral approach that is applied in the basin, i.e, responsibility for drinking water rests with one agency, for irrigation water with another, soil and water conservation with another, and for the environment with yet another, and lack of cross-sectoral linkages leads to uncoordinated water resource development and management, resulting in waste and unsustainable systems. It needs cross-sectoral approach to water management, in response to the growing competing demands for finite freshwater supplies.

Watershed management offers an effective method to intercept dispersed runoff. Many techniques of water conservation developed along hill slopes with the intention of preventing soil erosion and reducing surface runoff increases the infiltration in the ground. Soil and water conservation activities are not widely conducted in the study area although there is an effort to conduct watershed development adapted by Agriculture office at local level. But the selected watershed development is not effective because most farmers in the study areas lack awareness that soil erosion is the cause for declining crop yields and diminishing soil depth. Due to lack of awareness soil erosion problem is aggravated. soil erosion is the most common feature of land degradation, caused by human activities and is responsible for depleting soil productivity, destroying land and filling the reservoir by sediment which are easily observed in the lake Awassa catchment where the vegetation cover is very poor.

Currently inappropriate utilization of forest around the lake has resulted rapid acceleration of soil degradation in the catchment. Cultivation of steep slopes beyond their land capacity and without appropriate soil and water conservation practices and uncontrolled grazing on marginal lands have also aggravated the problems.

Hence the catchment needs soil and water conservation measures such as reforestation, construction of check dams across gullies, terracing etc. In general, a rehabilitation program is necessary to minimize erosion and flooding in the catchments. Better water and land management will help increase water availability and alleviate the impacts of natural catastrophes such as droughts. 


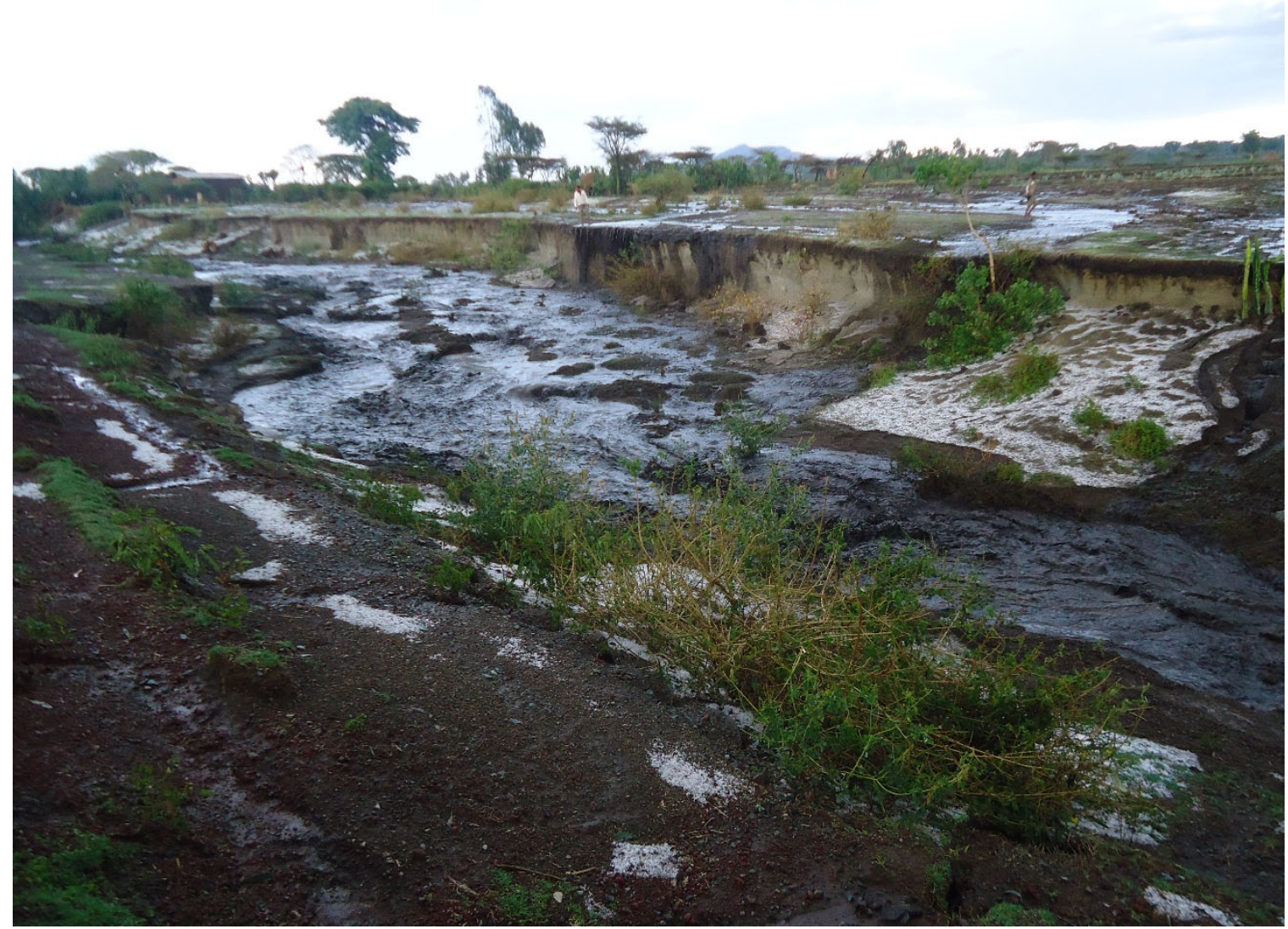

Figure 20. Runoff from Shashemene area towards Lake Awassa.

\section{Conclusions and Recommendations \\ 4.1 Conclusions}

The study area receives a mean annual rainfall of $1039.85 \mathrm{~mm}$. The mean annual actual evapotranspiration is $79.7 \%$ of the mean annual rainfall of the basin. Since the catchment is a closed basin, the main outflow component is evapotranspiration. Annual discharge of groundwater from boreholes, shallow wells, springs and hund dug wells for domestic and non domestic uses in the catchment is 17.8 million cubic meter. The mean annual surplus, which is available only for infiltration is $20.3 \%$ of the mean annual rainfall. The net total amount of water which is actually available to recharge the groundwater circulation within the Lake Awassa catchment is 218.79 million cubic meter. In general, the lake Awassa catchment has very good groundwater potential, if it is developed and utilized in controlled manner. According to the survey conducted in the study area, groundwater is mainly used for domestic and industrial purposes. Inventory of groundwater structures that was held in this study indicates that there are about 233 different types of groundwater structures found in difffernt parts of the study area. These structures are deep boreholes $(20.6 \%)$, shallow wells $(25.75 \%)$, hand dug wells $(18.89 \%)$ and developed springs $(34.76 \%)$. Even though these numbers of groundwater structures are found developed in the study area, however, the development of each of them was not based on earlier conducted investigation of groundwater in the catchment. Their development takes place without the knowledge of the groundwater potential of the area.

The major impediments for groundwater management in Lake Awassa catchment includes absence of basin institution, ineffective legal and regulatory framework, poor maintenance culture, poor technical and institutional capacity, lack of coordination, lack of community participation, poor planning and management practices and lack of monitoring and evaluation. An analysis of current practices lead to the conclusion that there is no effective system of groundwater management.

\subsection{Recommendations}

The following management options are recommended for optimum development, utilization and management of the groundwater resource of the Lake Awassa catchment.

- The traditional fragmented or purely sectoral approach is no longer viable and a cross-sectoral approach is essential in the basin for sustainable groundwater development and proper utilization and management.

- Groundwater development must be carried out in the context of an adequate catchment management plan.

- Utilization of groundwater from the structures should be conducted on the basis of recommended values 
that were set based on the hydrogeological parameters during the development of the structures.

- Enhance public awareness and knowledge of water resources management policy and water laws to become conscious of and sensitive to the groundwater.

\section{Acknowledgements}

The author would like to express his gratitude to prof. Nata Tadesse and Dr. Dessie Nedaw for providing technical support during this research. I gratefully acknowledge all offices and persons who have given me pertinent data for my study. The biggest share of my deepest heart felt gratitude goes to my wife, Azeb Tesfaye, and my baby sons Zerubbabel, Adonias and Christian who are the source of my strength and inspiration.

\section{References}

1. Proceeding of International conference and exhibition on groundwater in Ethiopia, 2004.

2. Thornthwaite, C.W and Mather, J.R. 1957. Instructions and tables for computing potential evapotranspiration and the water balance. New Jersey: Publication in Climatology, Centerton, X, No 3, pp. 185-204.

3. Leopold, L. B. and Dunne, T. 1978. Water in environmental planning. San Francisco: W. H.Freeman and Company.

4. Garg, K. 1987. Irrigation engineering and hydraulic structures. India: Khanna Publishers.

5. Ayenew, T., and Tilahun, N., 2008. Assessment of lake - groundwater interactions and anthropogenic stresses, using numerical groundwater flow model, for a Rift lake catchment in central Ethiopia. Blackwell Publishing Asia Pty Ltd, 13.

6. Alemayehu, T., 2008. Environmental resources and recent impacts in the Awassa collapsed caldera, Main Ethiopian Rift.

7. Woldegebreil, G., 1987. Volcanotectonic histery of the Central sector of the MER: A geochronological, geochemical and petrological approach, Unpub. Ph. D. Thesis, Clevland, Ohio, Case Western Reserve University, 410pp.

8. Dessie, T. and Tessema, Z.,(2003). Hydrogeology and Engineering geology of Awassa Lake catchment, Unpublished Report, Geological Survey of Ethiopia, Addis Ababa.

9. Ayenew, T., and Gebreegziabher, Y.,2006. Application of a spreadsheet hydrological model for computing the long-term water balance of Lake Awassa, Ethiopia.Hydrological Sciences Journal 51.

10. WWDSE (2001) The study of lake Awassa level rise. Unpublished Report Addis Ababa, Ethiopia.

11. Mekonnen,W." Conceptualization of groundwater flow system and aquifer characterization in Awassa Lake catchment". Unpublished MSc thesis, Addis Ababa University, Addis Ababa, Ethiopia,2005.

12. WoldeGebriel, G., Aronson, J.L., Walter, R.C, (1990). Geology, geochronology and rift basin development in the central sector of the Main Ethiopian Rift, Geol. Soc. Am. Bull., V-102, 439-458pp.

13. Ayenew, T. and Alemayehu, T.,2011. Principles of hydrogeology, Department of Geology and Geophysics, Addis Ababa University.Addis Ababa.

14. Llyod, E.F., 1977. Geological Factors Influencing Geothermal Exploration in the Langano Region, Ethiopia. N.Z. Geological Survey, Rotorua.

15. Shaw, E.M., (1988): Hydrology in practice. Second edition, Chapman and Hall, New York, 557pp.

16. Tadesse,N.,Tadios,S. \&Tesfaye,M.(2010).The water balance of May Nugus catchment,Tigray,Northern Ethiopia.International Journal of earth science and engineering. pp. 620-621.

17. Ritter, Michael E.,2006. The Physical Environment: an Introduction to Physical Geography. 